\title{
Establishing Standard Performance Scores and levels for battery of some basic skills tests in boxing for students at the Faculty of Physical Education *Dr/ Ahmed Rakha
}

\section{Abstract:}

This research aims to determine the standard performance scores and levels for battery of some basic skills tests in boxing for students at the Faculty of Physical Education. The researcher used (Rakha, 2016) battery to measure the basic skills in Boxing that involved in the course description of Boxing (1) for academic third level, Faculty of Physical Education in Port Said. The battery validity coefficient ranged between $(0.945-0.978)$ and the stability coefficient ranged between $(0.887-0.957)$ that indicates a high Validity and stability coefficients. Two hundred students in academic third level in faculty of physical education in Port-Said from consecutive two academic years (2015/2016 -100 Student) (2016/2017 -100 Student) responded to the battery tests. The researcher used (SPSS) software for conducted following statistical treatments: (Mean, Standard deviation, Skewness, t-test, Z-Score, T-Score). The most important results prepared the Z-scores and T-scores tables for each test and identified five standard levels (Novice - Advanced beginnerCompetent - Proficient - Expert) to explain the summative standard score obtained by the student through implementing the battery.

Keywords: Boxing, Test, Battery, Skills, Measure, Raw scores, Standard levels

\section{Introduction}

The evaluation of learning outcomes becomes the most important issues and effective quality criteria for developing appropriate methods, learning styles and teaching strategy to cover
learner needs of required
knowledge, skills and
competences. The field of
physical education witnessed
scientifically developments,

" Lecturer in Curriculum and Teaching Methods Department, Faculty of Physical Education for (Men- Girls) in Port-Said, Port-Said University. 
especially in evaluation processes, including objectivity tests and measurement tools to determine the standard scores and levels, which is an objective indicator to assess the academic achievement level of the students.

(Allawi and Radwan, 2008) indicates that evaluation process means the sentencing on the value of things or phenomena, this sentencing is based on the quantitative and qualitative description together, and includes standard levels to assess the efficiency and effectiveness of the things. And the relationship between the measurement, testing and evaluation is complementary. Measurement refers to the standardized procedures which their results are subject to statistical processing. It is the process of collecting information about the objects and determine the numerical values reflecting how much they owned the properties?. The test is a special measuring tool requiring a response from the individual which exported numbers or scores indicate to the type of her behavior or performance. Measurement and testing processes are necessary to determine the achievement of learning outcomes and the progress of the learner in the learning process, and it must precede the evaluation process, which creates the opportunity to take an appropriate decision.

(Allawi and Radwan, 2008) illustrate that collecting raw scores is easy procedure for measuring and testing, but the difficulty lies in the interpretation of the meaning of these scores. The standard scores and levels represents an urgent need for the teachers as one of the foundation's objectivity evaluation process, and through them they can evaluate the students at the end of the academic year in order to determine the level of each student in all the tests that apply to it. Because the units of measurement used in various tests is not one of a kind, so we had to put the solutions to these results through the use of statistics by converting raw scores to standard scores and can be summited any number of extracted results from tests that indicate the total score on the overall performance of the individual student from the various tests. The standard 
scores are a way to determine the relative situation of raw scores and thus can interpret these scores and evaluating their results.

(Salvia, Ysseldyke, \& Witmer 2009), (Neukrug and Fawcett, 2014) defined standard score as "the signed number of standard deviations by which the value of an observation or data point is above the mean value of what is being observed or measured". Raw scores above the mean have positive standard scores, while scores below the mean have negative standard scores". The standard score is "a dimensionless quantity obtained by subtracting the population mean from an individual raw score and then dividing the difference by the population standard deviation". Standard scores are also called z-values, z-scores, normal cores, and standardized variables. Boxing is one of the most important Olympic sports. In Egypt, there is a great interest in that, because their ability to compete and win medals at world championships and Olympic games. Therefore, it is one of the basic courses in the faculties of Physical Education. Learning basic skills in boxing is considered an important aspect due to its important role in changing the movement working conditions and exchange positive impact between boxers' contenders during the bout. In order to achieve the best results with economy of effort. So, there is an urgent need to assess the skill level of performance in boxing through the use of objective tests with legalized standard scores and performance skill levels, that enables teachers to evaluate and take appropriate decisions about students' performance skills and evaluate learning outcomes to develop methods, teaching strategies and improve the educational process.

\section{Research problem}

Boxing development came as a result to keep pace with developments in all fields of life in order to reach the best level of performance depending on the results of scientific research to take advantage of other sciences, especially, the field of measurement and evaluation. 
Through the work of a researcher in teaching boxing (1) course for the third-level students at the Faculty of Physical Education in Port Said, note that there are no objectively tests and standard scores to evaluate the skill levels of students in boxing. And the evaluation process based on the personal experience of the teacher which may not accurately reflect the performance level of some students in the evaluation process and a bias is most often in giving scores to students. Consequently, the research problem lies in the need to have some stability and appropriate standards to determine the level of the students in the performance of some basic skills in boxing sport. So, this research is a serious scientific try aim to set standard scores and levels by which to assess the level of some basic skills that involved in the course description of Boxing (1) for academic third level, Faculty of Physical Education in Port Said. And therefore, evaluate the learning outcomes at the practical side of the course Boxing (1) as one of the most important requirements in quality of the educational process.

\section{Research objectives}

Determine the standard performance scores and levels for battery of some basic skills tests in boxing for students at the Faculty of Physical Education.

\section{Research questions}

1. What are the standard scores (Z-score \& T-score) for each skill test in the battery of some basic skills tests in boxing?

2. What are the standard levels of performance skill to interpret the summative standard score that a student had obtained from testing battery in boxing for students at Faculty of Physical Education in Port Said?

\section{The terminology used in the research}

1. Basic skills in Boxing (Siegfried \& Ellwanger, 2008) defined basic skills in boxing as "The basic aimed movements that lead the boxer to apply attack and defend skills during the confrontation a competitor in the framework of the international law of boxing".

2. Test (Allawi \& Radwan, 2000) defined test as a "a 
situation designed to show a sample of the individual's behavior".

3. Testing Battery

(Hassanein, 1987) defined testing battery as "a group of several tests are applied respectively by the individual to achieve a desired objective".

4. RAW SCORES

(Hassanein, 2003) defined raw scores as "The original result based on applying the tests or any other measuring tool without being treated statistically" .

5. Standard Scores

(Hassanein, 2003) defined standard scores as "Degrees are expressing of each individual degree on the basis of number of units of standard deviation from the average so that we can compare it to other Degrees obtained by the reference group. Examples include Z-score, T-score, Percentile score".

6. Standard levels

(Allawi \& Radwan, 2000) defined standard levels as " standard criteria used to determine the relative status of raw scores in order to interpret these scores and evaluating their results".

Previous studies
(Shehab, Bashar., 2014). The research problem is that through the experience of the researcher as a teacher and coach for the sport of fencing, note the absence of grades and levels of standard for the skills of progress and retrogression normal in training Junior, prompting the researcher to study this problem is to determine grades and levels of standard for the skills of progress and retrogression normal for players emerging in the sport of fencing and to achieve biggest benefit of the teaching process and the training and the economy at the time and effort and money to reach higher levels and achieve the best achievements through the selection of talented people.

The study aimed to identify the level of advance and retreat skills in fencing for the subjects of the study and determine the grades and standard levels of advance and retreat skills in fencing for the subjects of the study. The descriptive approach has been used by the researchers for its suitability with the nature of the study. The subjects included (100) students out of 
(108) students representing $92.59 \%$ of the original community. The statistical treatments used by the researchers consisted of the $(\%$ percentage, $\mathrm{Z}$ degree, modified standard degree). The researchers concluded that:

- Testing the skills of advance and retreat, the results of the majority of the subjects confined between the two levels (average, acceptable) and a small percentage confined between (very good, good). Testing the skill of advance, the results of largest proportion of the subjects limited within the level (acceptable), followed by level (average) but with a little difference. Testing the skill of retreat, the results of largest proportion of the subjects limited within the level (acceptable), followed by level (average).

(Salum, Ali., Jassim, Mazen., \& Amin, Walid., 2012) The research aims to determine the standard levels of some of the basic skills of basketball for the students of the first phase in the faculties of Physical Education, The research sample was included (102) students conducted their tests (Dribbling ended Shooting test - Speed of Dribbling Test - Passing on the wall test - Passing with one hand test), as they were the most important conclusions determining standard levels for the tests and divided into six levels as well as the distribution of the sample was very close to the normal distribution.

(Al-Zubaidi,

Ashraf.,2008) It has been assigned in this research marks and evaluated levels for some of the charging skills for the basketball wheel chair sitter's players and the study included the abilities and skills of offensiveness represented in (direct aiming to the goal, direct chest reception, free kick and the long shoulder reception in order) to know the average standard for these players by way of exercises which had been implemented and represented in the changes under study. The number of the sample that have been applied testing for them is of 10 players from Wesam Almajd club representing the basketball team this number accounts for $100 \%$ of the original research community. 
These average standards had been limited according to groups that the players were distributed upon according to the value of injury or the value of disability, which it has a serious effect in limiting the average standards. One of the most important conclusions, which the researcher had reached upon, is the exercises average was below the required standard where the implementation of all the exercises appeared that it was in intermediate level, and weak in acceptance. In addition, in one of the exercises it appeared at the acceptable level, which would mean weakness of the players in such offensive capabilities and skills.

$$
\text { (Anzi,A., }
$$

Ahmed.,\&

Al-saqqi, Alaab.,2008) The importance of the research lies in finding standard classes and levels for some basic offensive skills in Basketball in which there are no constant standards that measure the student's performance in Basketball. The problem of the study appears skills of when we try to measure the levels of the students in Basketball and there are. The research aims at
Applying standard classes and levels for some basic offensive skills in Basketball. The samples of data included 60 students out of 70 after excluding a female student from the first grade in Physical Education Dept. College of Basic Education in the period between 1/11/2007 and $1 / 2 / 2008$ and the data collection has become $85.71 \%$ out of the main data analyses. Throughout the statistical treatment of the data analyses, the research has come up with the following conclusion: (1) That the tests used for the basic skills are suitable for the level of the basic analyses. (2) Standard classes and levels for measuring the basic skills in Basketball have been found. (3) The most individuals of the data collection are in the medium standard level.

\section{Method}

The researcher used the descriptive method, as this is more suitable for the nature of the research.

\section{Research population and sample}

Research population

Research population included the students at Faculty of Physical Education in Port Said 
in academic third level that studied Boxing (1) course. The researcher deliberately chose this population because their previous experience in boxing sport.

\section{Sample Size}

The researcher selected randomly (200 students) from consecutive two academic years as follows:

1- Academic year 2015/2016 AD (100 Student)

2- Academic year 2016/2017 AD (100 Student)
Where already studied course Boxing (1) For Boys - and they have the experience to perform basic skills in boxing. The researcher deliberately chooses the sample over consecutive years for increasing the sample size to get more accurate standard scores, as well as keep track of the stability of the results average of students in the skills tests over the years in a row.

The homogeneity and equivalence of the sample:

\section{Table (1)}

Group1 (Students in academic year 2015/2016 AD $n=100$ ) Minimum, Maximum value, Means \& SD of Skewness for weight, height, age, IQ, general fitness, and Boxing basic skills tests

\begin{tabular}{|c|c|c|c|c|c|c|c|c|}
\hline \multirow{2}{*}{\multicolumn{2}{|c|}{ Variables }} & \multirow{2}{*}{ 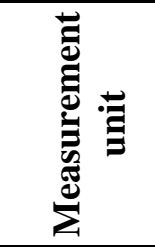 } & \multirow{2}{*}{ 志 } & \multirow{2}{*}{ 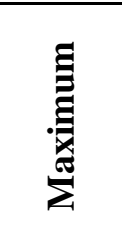 } & \multirow{2}{*}{ 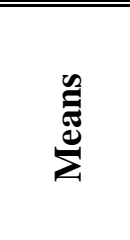 } & \multirow[b]{2}{*}{ ค } & \multicolumn{2}{|c|}{ Skewness } \\
\hline & & & & & & & $\cong$ & ప \\
\hline 1 & Height & $\mathrm{Cm}$ & 160.00 & 190.00 & 175.69 & 6.63 & -.25 & .241 \\
\hline 2 & Weight & $\mathrm{Kg}$ & 53.00 & 103.00 & 74.05 & 10.89 & .56 & .241 \\
\hline 3 & Age & Year/day & 20.32 & 24.20 & 21.68 & 0.81 & 1.20 & .241 \\
\hline 4 & IQ & Degree & 3.00 & 90.00 & 26.45 & 20.48 & 1.04 & .241 \\
\hline 5 & General Fitness & Degree & 18.15 & 36.36 & 28.60 & 6.63 & -.25 & .241 \\
\hline $\begin{array}{l}6- \\
1\end{array}$ & $\begin{array}{l}\text { Stance \& foot } \\
\text { work evaluation } \\
(\mathrm{S} \& \mathrm{FW})\end{array}$ & Degree & 3.00 & 9.00 & 5.70 & 1.65 & .29 & .241 \\
\hline
\end{tabular}

\section{Follow Table (1)}

Group1 (Students in academic year 2015/2016 AD $n=100$ ) Minimum, Maximum value, Means \& SD of Skewness for weight, height, age, IQ, general fitness, and Boxing basic skills tests 


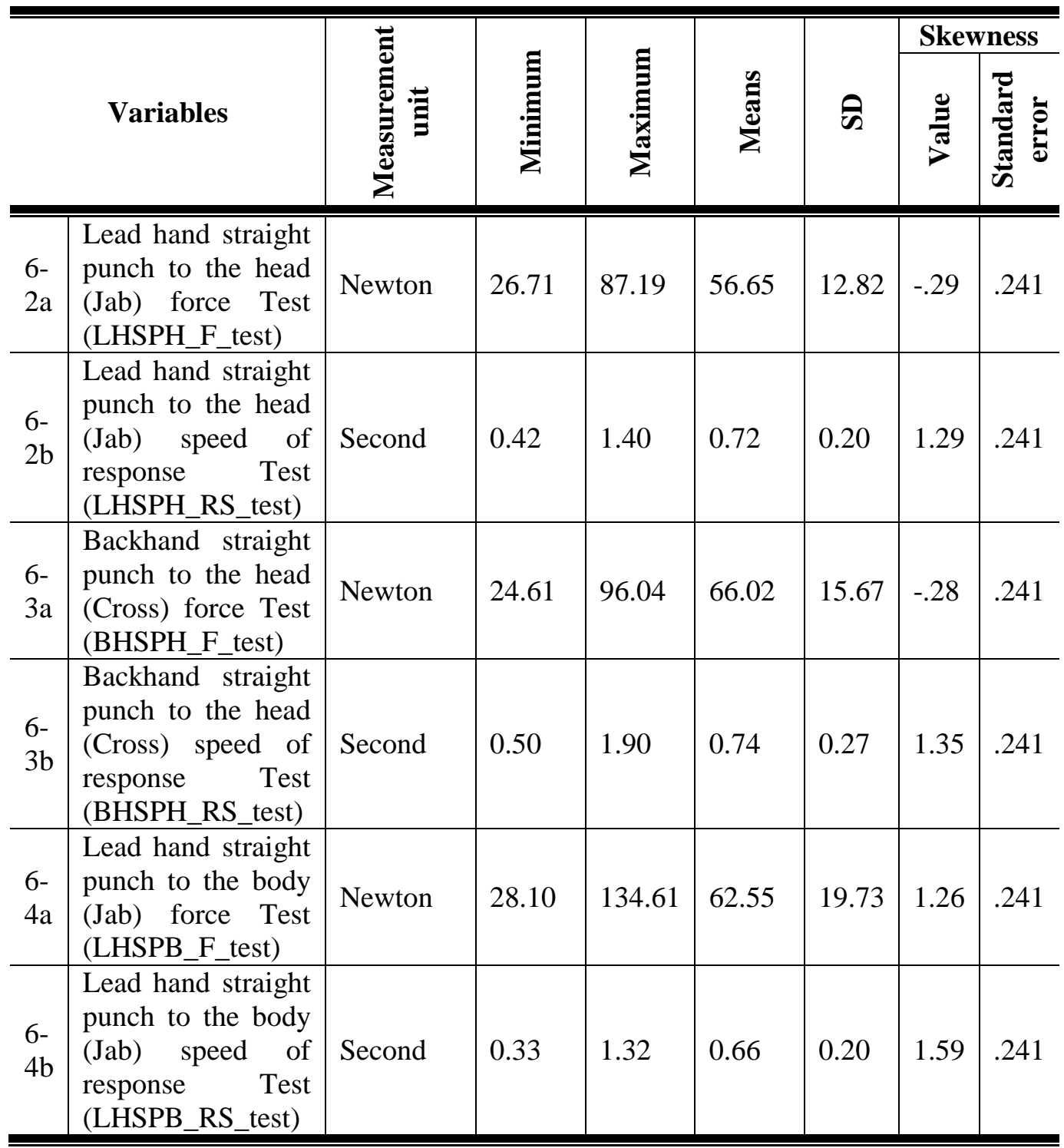

Follow Table (1)

Group1 (Students in academic year 2015/2016 AD $n=100$ )

Minimum, Maximum value, Means \& SD of Skewness for weight, height, age, IQ, general fitness, and Boxing basic skills tests

Assiut Journal For Sport Science Arts 


\begin{tabular}{|c|c|c|c|c|c|c|c|c|}
\hline & & & & & & & Ske & vness \\
\hline & Variables & 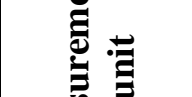 & 声 & $\stackrel{\Xi}{\Xi}$ & 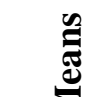 & क्ष & $\stackrel{\mathscr{E}}{=}$ & تِ \\
\hline $\begin{array}{l}6- \\
5 a\end{array}$ & $\begin{array}{l}\text { Backhand straight } \\
\text { punch to the body } \\
\text { (Cross) force Test } \\
\text { (BHSPB_F_test) }\end{array}$ & Newton & 35.74 & 139.10 & 69.54 & 18.50 & 1.01 & .241 \\
\hline $\begin{array}{l}6- \\
5 b\end{array}$ & $\begin{array}{l}\text { Backhand straight } \\
\text { punch to the body } \\
\text { (Cross) speed of } \\
\text { response Test } \\
\text { (BHSPB_RS_test) }\end{array}$ & Second & 0.45 & 1.09 & 0.67 & 0.14 & 1.32 & .241 \\
\hline $\begin{array}{l}6- \\
6\end{array}$ & $\begin{array}{l}\text { The speed of Jab- } \\
\text { cross combination } \\
\text { punches in the } 30^{\text {th }} \\
\text { test } \\
\text { (JCCPs_S_30 } \\
\text { th test) }\end{array}$ & Counting & 39.00 & 88.00 & 58.56 & 15.38 & .42 & .241 \\
\hline $\begin{array}{l}6- \\
7\end{array}$ & $\begin{array}{l}\text { The speed of one } \\
\text { Jab-cross } \\
\text { combination punch } \\
\text { test (One } \\
\text { JCCPs_S_test) }\end{array}$ & $\begin{array}{l}1 / 100 \text { th of } \\
\text { a second }\end{array}$ & 0.11 & 0.41 & 0.22 & 0.07 & .91 & .241 \\
\hline $\begin{array}{l}6- \\
8\end{array}$ & $\begin{array}{l}\text { The speed of one } \\
\text { Cross-jab } \\
\text { combination punch } \\
\text { test (One } \\
\text { CJPs_S_test) }\end{array}$ & $\begin{array}{l}\text { 1/100th of } \\
\text { a second }\end{array}$ & 0.10 & 0.33 & 0.20 & 0.05 & .41 & .241 \\
\hline
\end{tabular}

From (Table 1) it is clear that skews values ranged between $(-0.29$ and 1.35) for research sample, values between $+/-3$ reflecting the sample homogeneity on the variables of weight, height, age, IQ, general fitness, and Boxing basic skills tests.

\section{Table (2)}

Group2 (Students in academic year 2016/2017 AD n=100) Minimum, Maximum value, Means \& SD of Skewness for weight, height, age IQ, general fitness, and Boxing basic skills tests 


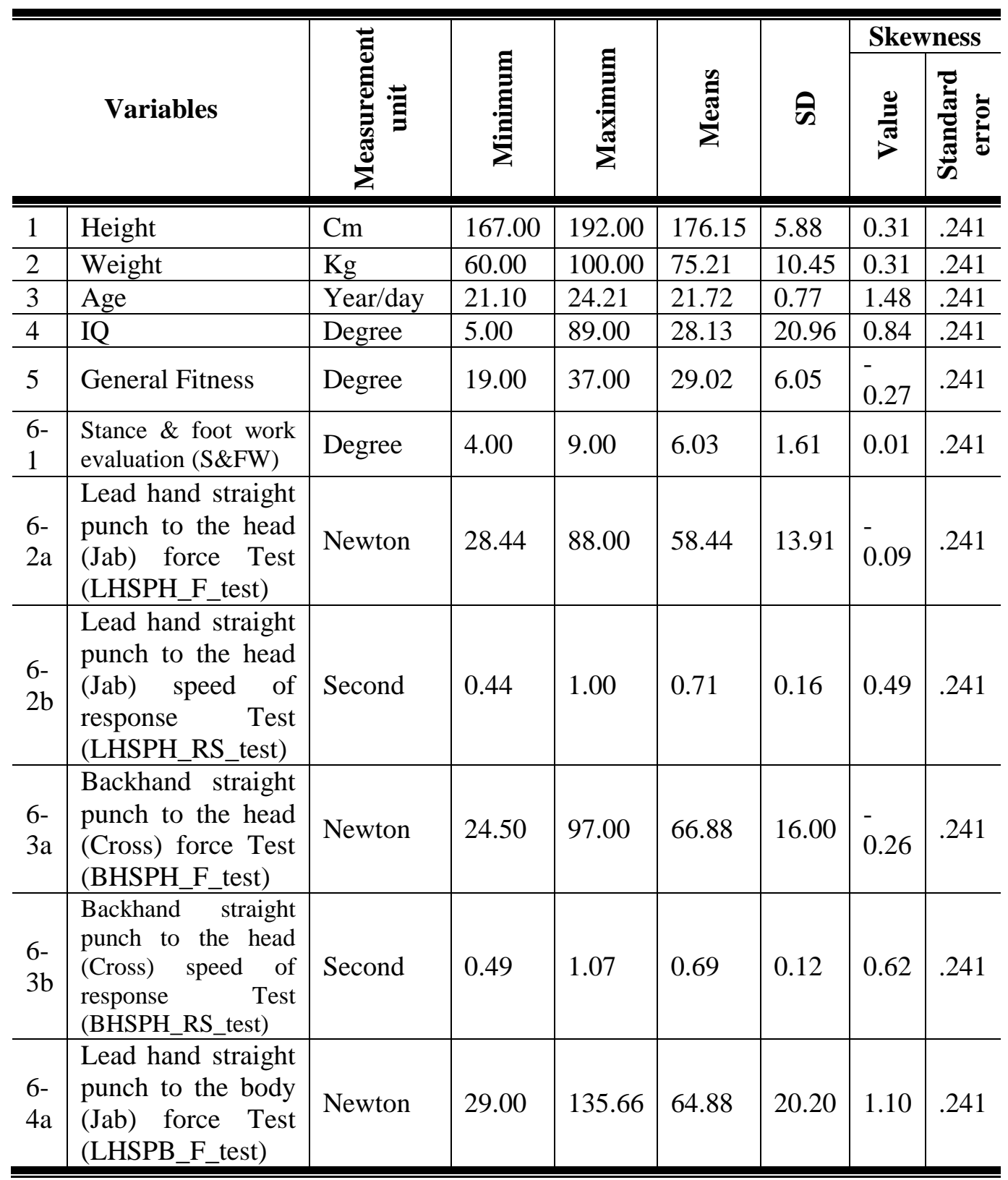

\section{Follow Table (2)}

Group2 (Students in academic year 2016/2017 AD $\mathbf{n = 1 0 0 )}$

Minimum, Maximum value, Means \& SD of Skewness for weight, height, age IQ, general fitness, and Boxing basic skills tests 


\begin{tabular}{|c|c|c|c|c|c|c|c|c|}
\hline \multirow{2}{*}{\multicolumn{2}{|c|}{ Variables }} & \multirow{2}{*}{ 胥 } & \multirow{2}{*}{ 䍕 } & \multirow{2}{*}{$\underset{\sum}{\stackrel{\Xi}{\Xi}}$} & \multirow{2}{*}{ 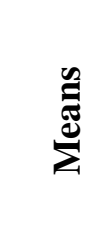 } & \multirow[b]{2}{*}{$\theta$} & \multicolumn{2}{|c|}{ Skewness } \\
\hline & & & & & & & $\stackrel{\varrho}{\Xi}$ & 를 \\
\hline $\begin{array}{l}6- \\
4 b\end{array}$ & $\begin{array}{l}\text { Lead hand straight } \\
\text { punch to the body } \\
\text { (Jab) speed of } \\
\text { response } \\
\text { (LHSPB_RS_test) }\end{array}$ & Second & 0.30 & 1.35 & 0.65 & 0.20 & 1.58 & .241 \\
\hline $\begin{array}{l}6- \\
5 a\end{array}$ & $\begin{array}{l}\text { Backhand straight } \\
\text { punch to the body } \\
\text { (Cross) force Test } \\
\text { (BHSPB_F_test) }\end{array}$ & Newton & 35.00 & 139.80 & 68.46 & 19.60 & 0.92 & .241 \\
\hline $\begin{array}{l}6- \\
5 b\end{array}$ & $\begin{array}{l}\text { Backhand straight } \\
\text { punch to the body } \\
\text { (Cross) speed of } \\
\text { response Test } \\
\text { (BHSPB_RS_test) }\end{array}$ & Second & 0.40 & 1.15 & 0.69 & 0.15 & 1.03 & .241 \\
\hline $\begin{array}{l}6- \\
6\end{array}$ & $\begin{array}{l}\text { The speed of Jab- } \\
\text { cross combination } \\
\text { punches in the } 30^{\text {th }} \\
\text { test } \\
\text { (JCCPs_S_30 th test) }\end{array}$ & Counting & 38.00 & 99.00 & 60.23 & 15.56 & 0.45 & .241 \\
\hline $\begin{array}{l}6- \\
7\end{array}$ & $\begin{array}{l}\text { The speed of one Jab- } \\
\text { cross combination } \\
\text { punch test (One } \\
\text { JCCPs_S_test) }\end{array}$ & $\begin{array}{l}\text { 1/100th of } \\
\text { a second }\end{array}$ & 0.10 & 0.43 & 0.21 & 0.08 & 0.63 & .241 \\
\hline $\begin{array}{l}6- \\
8\end{array}$ & $\begin{array}{l}\text { The speed of one } \\
\text { Cross-jab combination } \\
\text { punch test (One } \\
\text { CJPs_S_test) }\end{array}$ & $\begin{array}{l}\text { 1/100th of } \\
\text { a second }\end{array}$ & 0.09 & 0.34 & 0.21 & 0.06 & 0.54 & .241 \\
\hline & $\begin{array}{l} \\
\text { From (Table } \\
\text { that skews valı } \\
\text { between }(-0.27 \text { an } \\
\text { research sampl }\end{array}$ & $\begin{array}{l}\text { 2) it is clea } \\
\text { es range } \\
\text { d } 1.58) \text { fo } \\
\text { value }\end{array}$ & & $\begin{array}{l}\text { sample } \\
\text { variable } \\
\text { age, IQ } \\
\text { Boxing }\end{array}$ & $\begin{array}{l}\text { homo } \\
\text { of } \\
\text { gene } \\
\text { asic s }\end{array}$ & $\begin{array}{l}\text { eity } \\
\text { ight, } \\
\text { fitnes } \\
\text { s tests. }\end{array}$ & $\begin{array}{l}\mathrm{n} \text { th } \\
\text { height } \\
\text {, ant }\end{array}$ & \\
\hline
\end{tabular}

Table (3)

Groups equivalence on weight, height, age, IQ, general fitness, and Boxing basic skills tests $\left(G 1^{*}=100, G_{2}^{* * *}=100\right)$ 


\begin{tabular}{|c|c|c|c|c|c|c|c|c|c|}
\hline \multirow{2}{*}{ No } & \multirow{2}{*}{ Variables } & \multirow{2}{*}{ 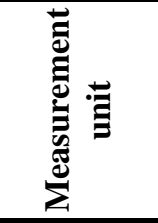 } & \multicolumn{2}{|c|}{$\begin{array}{c}\text { Group1 } \\
2015 / 2016 \\
\end{array}$} & \multicolumn{2}{|c|}{$\begin{array}{c}\text { Group2 } \\
2016 / 2017 \\
\end{array}$} & \multirow{2}{*}{ 芯递 } & \multirow{2}{*}{$\mathbf{t}$} & \multirow{2}{*}{$\begin{array}{c}\text { Sig } \\
(2- \\
\text { tailed }\end{array}$} \\
\hline & & & Means & SD & Means & SD & & & \\
\hline 1 & Height & $\mathrm{Cm}$ & 175.690 & 6.63 & 176.150 & 5.88 & $\overline{-} .460$ & $\overline{-} .52$ & 0.60 \\
\hline 2 & Weight & $\mathrm{Kg}$ & 74.050 & 10.89 & 75.210 & 10.45 & $\begin{array}{l}- \\
1.160 \\
\end{array}$ & $\overline{-} .77$ & 0.44 \\
\hline 3 & Age & Year/day & 21.682 & 0.81 & 21.717 & 0.77 & $\overline{-}-035$ & $\overline{-} .32$ & 0.75 \\
\hline 4 & IQ & Degree & 26.450 & 20.48 & 28.130 & 20.96 & $-\overline{1.680}$ & $-\overline{-} .57$ & 0.57 \\
\hline 5 & General Fitness & Degree & 28.599 & 6.63 & 29.017 & 6.05 & $\overline{0}-418$ & $\overline{0.47}$ & 0.64 \\
\hline $\begin{array}{l}6- \\
1\end{array}$ & S\&FW & Degree & 5.700 & 1.65 & 6.030 & 1.61 & $\overline{0}-330$ & $-\overline{1.43}$ & 0.15 \\
\hline $\begin{array}{l}6- \\
2 a \\
\end{array}$ & LHSPH_F_test & Newton & 56.654 & 12.82 & 58.444 & 13.91 & $\overline{-} .790$ & $\overline{0} .95$ & 0.35 \\
\hline $\begin{array}{l}6- \\
2 b\end{array}$ & LHSPH_RS_test & Second & 0.724 & 0.20 & 0.705 & 0.16 & 0.018 & 0.71 & 0.48 \\
\hline $\begin{array}{l}6- \\
3 a \\
\end{array}$ & BHSPH_F_test & Newton & 66.019 & 15.67 & 66.884 & 16.00 & $\begin{array}{l}- \\
0.865\end{array}$ & $-\overline{0} .39$ & 0.70 \\
\hline $\begin{array}{l}6- \\
3 b\end{array}$ & BHSPH_RS_test & Second & 0.736 & 0.27 & 0.689 & 0.12 & 0.047 & 1.61 & 0.11 \\
\hline $\begin{array}{l}6- \\
4 a \\
\end{array}$ & LHSPB_F_test & Newton & 62.547 & 19.73 & 64.878 & 20.20 & $-\overline{2.331}$ & $\overline{0} .83$ & 0.41 \\
\hline $\begin{array}{l}6- \\
4 b\end{array}$ & LHSPB_RS_test & Second & 0.658 & 0.20 & 0.648 & 0.20 & 0.010 & 0.35 & 0.73 \\
\hline $\begin{array}{l}6- \\
5 \mathrm{a} \\
\end{array}$ & BHSPB_F_test & Newton & 69.540 & 18.50 & 68.460 & 19.60 & 1.080 & 0.40 & 0.69 \\
\hline $\begin{array}{l}6- \\
5 b \\
\end{array}$ & BHSPB_RS_test & Second & 0.672 & 0.14 & 0.688 & 0.15 & $-\overline{0}$ & $\overline{-}$ & 0.42 \\
\hline $\begin{array}{l}6- \\
6 \\
\end{array}$ & JCCPs_S_30thtest & Counting & 58.560 & 15.38 & 60.230 & 15.56 & $\begin{array}{l}- \\
1.670\end{array}$ & - & 0.45 \\
\hline $\begin{array}{l}6- \\
7 \\
\end{array}$ & $\begin{array}{l}\text { One } \\
\text { JCCPs_S_test }\end{array}$ & $\begin{array}{l}\text { 1/100th of } \\
\text { a second }\end{array}$ & 0.222 & 0.07 & 0.214 & 0.08 & 0.008 & 0.79 & 0.43 \\
\hline $\begin{array}{l}6- \\
8\end{array}$ & $\begin{array}{l}\text { One } \\
\text { CJCPs_S_test }\end{array}$ & $\begin{array}{l}\text { 1/100th of } \\
\text { a second }\end{array}$ & 0.205 & 0.05 & 0.207 & 0.06 & $\overline{-} .002$ & $-\overline{0} .21$ & 0.83 \\
\hline
\end{tabular}

From (Table 3) it is clear that $(\mathrm{t})$ value from Independent samples T-test test of the significance of differences between two measurements for each of group1(Students in academic year 2015/2016 AD $\mathrm{n}=100$ ) and group2 (Students in academic year 2016/2017 AD $n=100$ ) in height, weight, 
age , IQ, general fitness, and Boxing basic skills tests is not statistically significant at level (0.05), because the significance levels values ranged between $(0.06,0.75)$ and largest than significance level (0.05), this means that the differences between the two groups is not real and in these variables.

The Devices and tools used in research

1. Restameter device to measure the height to nearest $1 / 2$ $\mathrm{cm}$.

2. Electronic scale device to measure weight to nearest $1 / 2$ $\mathrm{kg}$.

3. High intelligence test prepared by El-Said Mohamed Khairy.(Khairy, ND).

4. Fitness Battery for admission to the Faculty of
Physical Education in Port Said.

5. Mega-Strike device: This device uses to measure the punching force by using the sensor Approx. $275 \times 200 \mathrm{~mm}$ (Size of star and text) connected to processor to convert this punching to the numerical value. In addition, measures the speed of the reaction, and show the value of time per second on an electronic display. The researcher calibrated MegaStrike device to measure punching force in boxing sport through the equation of the correction used in converting values of Mega-strike device to the quantitative amount is $\mathrm{Mr}=$ (0.780 $\times$ Megastrike value) $+17.90$

(Rakha, 2013)

$F=\frac{M \text { By Ragremionpreditureformala }}{\text { Time from (mega-strike) }}$.

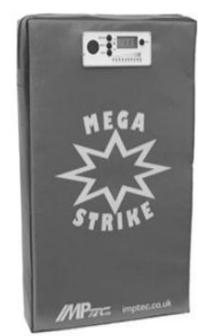

Figure (1) Mega-Strike device

6. COUNT-N-TIME device

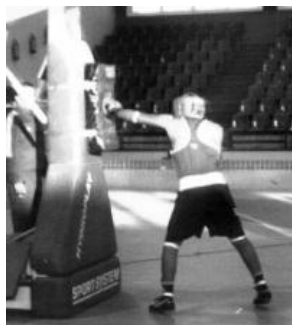


This device is used for the following:

- Counts the number of good strikes in a time period (up to 90 seconds)

- Times a preset number of strikes (up to 990) to nearest

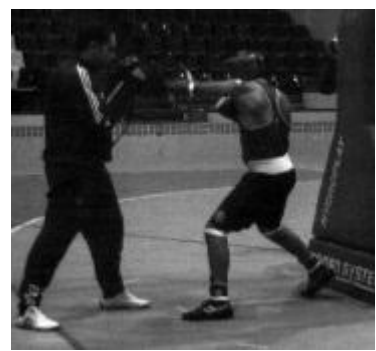

Figure (2) COUNT-N-TIME device

7. The battery of some basic skills tests in boxing (Rakha,2016) extracted tests as a battery to measure the basic skills in Boxing that involved in the course description of Boxing (1) for academic third level, Faculty of Physical Education in Port 1/10th of a second (up to 99.9 seconds

- Times a preset
combination (up to 9 strikes) to
nearest $1 / 100$ th of a second

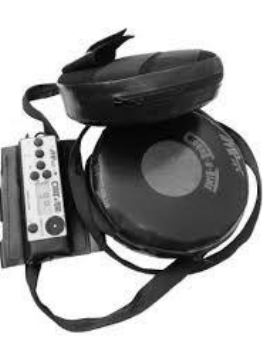

Said. The battery validity coefficient ranged between $(0.945-0.978)$ and the stability coefficient ranged between (0.887 - 0.957) that indicates a high Validity and stability coefficients. Table 4 shows the battery of some basic skills tests in boxing.

Table (4)

The battery of some basic skills tests in boxing.

\begin{tabular}{|c|c|c|c|c|c|}
\hline No & Skills & Test & Unit & Test Description & Image \\
\hline 1 & $\begin{array}{l}\text { Stance \& } \\
\text { foot work }\end{array}$ & $\begin{array}{l}-\quad \text { Stance } \\
\& \text { foot work } \\
\text { evaluation }\end{array}$ & Degree & $\begin{array}{l}\text { - Instruments: } \\
\text { Performance } \\
\text { Evaluation Card } \\
\text { - Performance } \\
\text { specifications: } \\
\text { Boxer performing the } \\
\text { stands ready and } \\
\text { footwork, the evaluator } \\
\text { assesses the } \\
\text { performance of Stance } \\
\text { \& foot work according }\end{array}$ & \\
\hline
\end{tabular}

Assiut Journal For Sport Science Arts 


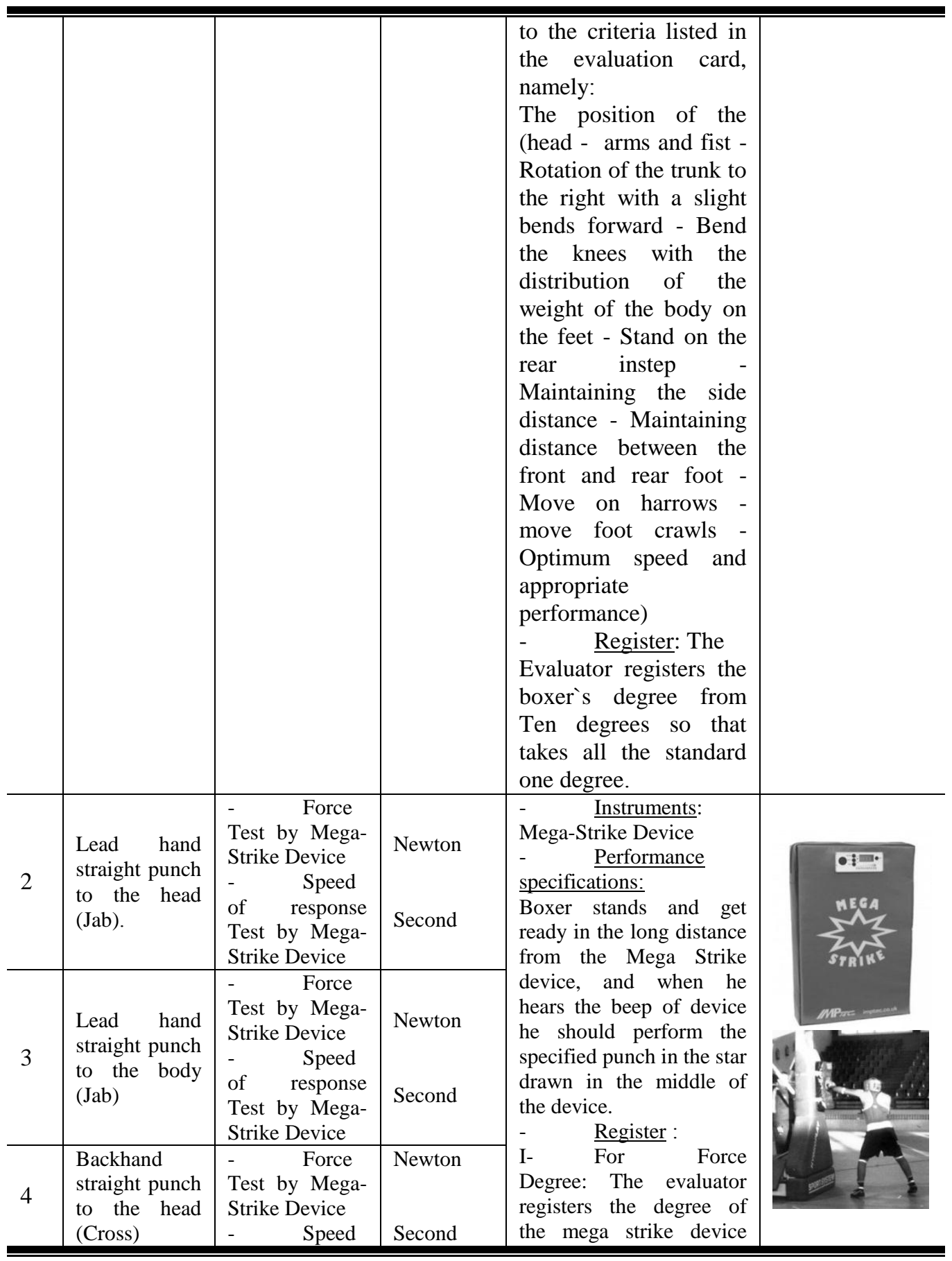

Assiut Journal For Sport Science Arts 


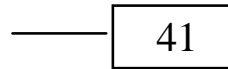

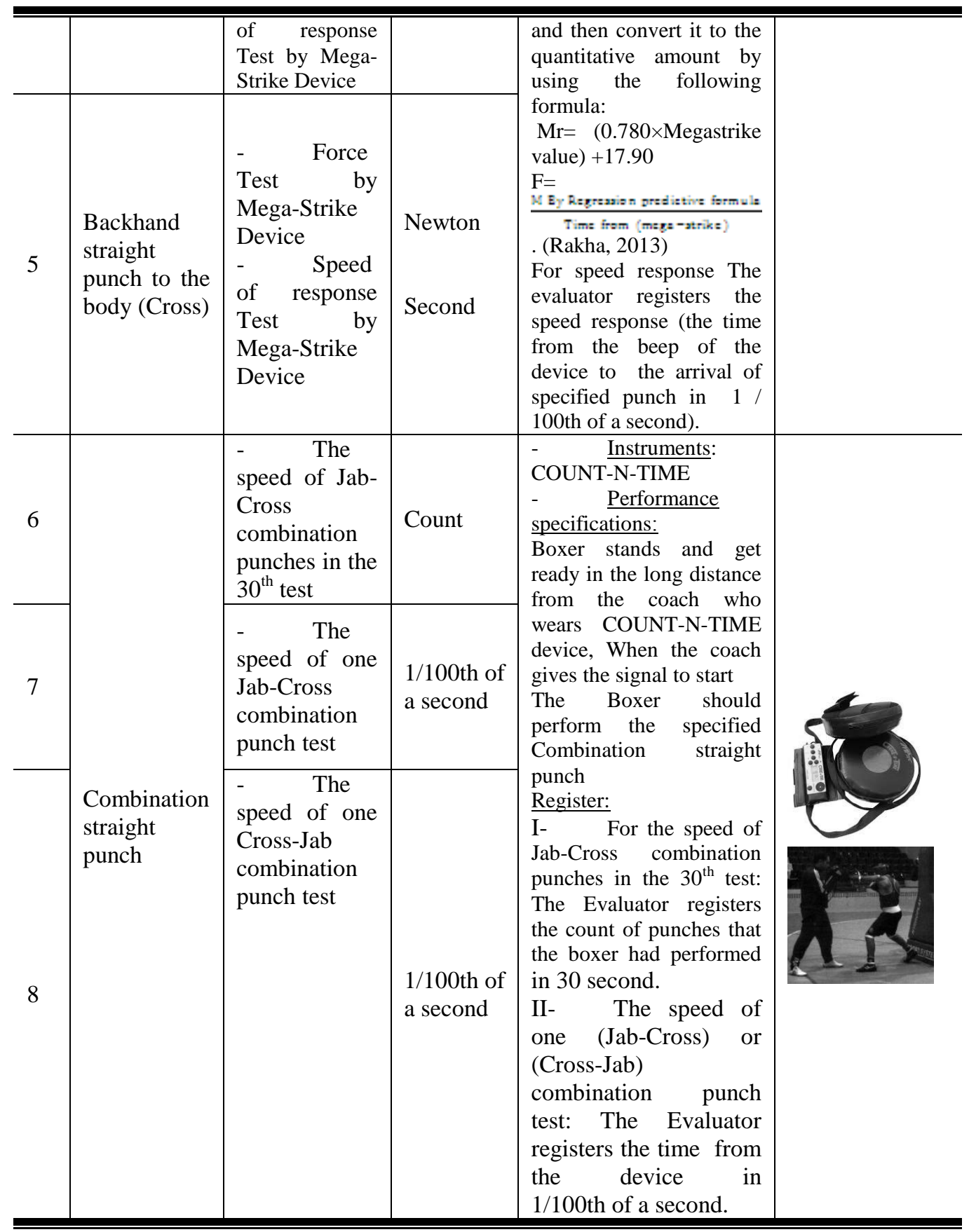




\section{The Basic measurements:}

The researcher with her assistant team conducting the basic measurements by using the battery of some basic skills tests in boxing (Rakha,2016) on 200 students over two times as follow:

First time: from 16-17 / $3 / 2016$, the research sample reached (100 student) from third level in academic year 2015/2016 AD. The researcher, implemented the testing battery of fifty students per day.

Second time: from 2-3 $/ 11 / 2016$, the research sample reached (100 student) from third level in academic year 2016/2017 AD. The researcher, implemented the testing battery of fifty students per day.

\section{Statistical treatment}

The researcher used (SPSS) software for conducted following statistical treatments: (Mean, Standard deviation, Skewness, t-test, Z-Score, TScore).

$$
\mathrm{z}=\frac{\mathrm{X}-\mu}{\sigma}
$$

Results

1. Present the results of the first question " What are the standard scores (Z-score \& $\mathrm{T}$ score) for each skill test in the battery?"

The researcher converts raw scores to standard scores, which is a way to determine the relative situation of raw scores, and get a summative standard score which represent the level of skills and used for the evaluation process.

The researcher using the Reciprocal method that referred by (Allawi and Radwan, 2000) to calculate the standard Z -Score \& T-Score. Z-Score indicate the position for the distribution according to the units of standard deviation, which is located above or below the arithmetic mean. So, these values are positive or negative, and the mean of standard Z-Scores is (zero) and standard deviation is (1). To calculate Z-score using the following equation: 
$\mu=$ Mean $\quad \mathrm{x}=$ row value

$\sigma=$ standard deviation

The adjusted standard Score

(T) is the modification of the Z-Score characterized as not include negative values and can be gathered, the mean $\mathrm{T}$ score is (50) and standard deviation is (10). To calculate a $\mathrm{T}$-score using the following equation $\mathrm{T}=(10 \times \mathrm{Z})+50$

Reciprocal Value is a constant value is added to the Z-Score or T-Score to get the following standard score of raw degrees sequentially. To calculate Reciprocal Value using the following equations:
Reciprocal Value for $\mathrm{Z}$ score $=$ $\frac{\sigma \text { for } \mathrm{Z} \text {-scores }}{\sigma \text { for row scores }}$

Reciprocal Value for $\mathrm{T}$ score $=$ $\frac{\sigma \text { for } \mathrm{T} \text {-scores }}{\sigma \text { for row scores }} \quad$ (Allawi and

Radwan, 2000)

The researcher used Micosoft excel 2013 software to calculate the Z-Score \& TScore sequentially by using the mean and standard deviation of the entire sample $(\mathrm{N}=200$ Student), As it is shown in Table (5)

Table (5)

Descriptive Statistics for the entire sample ( $N=200$ Student)

\begin{tabular}{c|l|c|c|c|c|c}
\hline \hline \multicolumn{2}{l|}{ Variables } & $\begin{array}{l}\text { Measurement } \\
\text { unit }\end{array}$ & Minimum & Maximum & Means & SD \\
\hline \hline 1 & $\begin{array}{l}\text { Stance \& foot } \\
\text { work evaluation } \\
\text { (S\&FW) }\end{array}$ & Degree & 3.00 & 9.00 & 5.87 & 1.63 \\
\hline $\mathrm{a}$ & $\begin{array}{l}\text { Lead hand straight } \\
\text { punch to the head } \\
\text { (Jab) force Test } \\
\text { (LHSPH_F_test) }\end{array}$ & $\begin{array}{l}\text { Lead hand straight } \\
\text { punch to the head } \\
\text { (Jab) speed of } \\
\text { response Second } \\
\text { (LHSPH_RS_test) }\end{array}$ & 26.71 & 88.00 & 57.55 & 13.37 \\
\hline $3 \mathrm{a}$ & $\begin{array}{l}\text { Backhand straight } \\
\text { punch to the head } \\
\text { (Cross) force Test } \\
\text { (BHSPH_F_test) }\end{array}$ & Newton & 24.50 & 97.00 & 66.45 & 15.80 \\
\hline \hline
\end{tabular}

Assiut Journal For Sport Science Arts 
Follow Table (5)

Descriptive Statistics for the entire sample ( $N=200$ Student)

\begin{tabular}{|c|c|c|c|c|c|c|}
\hline \multicolumn{2}{|c|}{ Variables } & $\begin{array}{l}\text { Measurement } \\
\text { unit }\end{array}$ & Minimum & Maximum & Means & SD \\
\hline $3 b$ & $\begin{array}{l}\text { Backhand straight } \\
\text { punch to the head } \\
\text { (Cross) speed of } \\
\text { response Test } \\
\text { (BHSPH_RS_test) }\end{array}$ & Second & 0.49 & 1.90 & 0.71 & 0.21 \\
\hline $\begin{array}{l}6- \\
4 a\end{array}$ & $\begin{array}{l}\text { Lead hand straight } \\
\text { punch to the body } \\
\text { (Jab) force Test } \\
\text { (LHSPB_F_test) }\end{array}$ & Newton & 28.10 & 135.66 & 63.71 & 19.95 \\
\hline $4 b$ & $\begin{array}{l}\text { Lead hand straight } \\
\text { punch to the body } \\
\text { (Jab) speed of } \\
\text { response Test } \\
\text { (LHSPB_RS_test) }\end{array}$ & Second & 0.30 & 1.35 & 0.65 & 0.20 \\
\hline $5 a$ & $\begin{array}{l}\text { Backhand straight } \\
\text { punch to the body } \\
\text { (Cross) force Test } \\
\text { (BHSPB_F_test) }\end{array}$ & Newton & 35.00 & 139.80 & 69.00 & 19.02 \\
\hline $5 b$ & $\begin{array}{l}\text { Backhand straight } \\
\text { punch to the body } \\
\text { (Cross) speed of } \\
\text { response Test } \\
\text { (BHSPB_RS_test) }\end{array}$ & Second & 0.40 & 1.15 & 0.68 & 0.14 \\
\hline 6 & $\begin{array}{l}\text { The speed of Jab- } \\
\text { cross combination } \\
\text { punches in the } 30^{\text {th }} \\
\text { test } \\
\text { (JCCPs_S_30 } \\
\text { th test) }\end{array}$ & Counting & 38.00 & 99.00 & 59.40 & 15.45 \\
\hline 7 & $\begin{array}{l}\text { The speed of one } \\
\text { Jab-cross } \\
\text { combination punch } \\
\text { test (One } \\
\text { JCCPs_S_test) }\end{array}$ & $\begin{array}{c}\text { 1/100th of a } \\
\text { second }\end{array}$ & 0.10 & 0.43 & 0.22 & 0.07 \\
\hline 8 & $\begin{array}{l}\text { The speed of one } \\
\text { Cross-jab } \\
\text { combination punch } \\
\text { test (One } \\
\text { CJPs_S_test) }\end{array}$ & $\begin{array}{c}\text { 1/100th of a } \\
\text { second }\end{array}$ & 0.09 & 0.34 & 0.21 & 0.06 \\
\hline
\end{tabular}


The tables $(6,7,8,9$, $10,11, \quad 12,13, \quad 14,15, \quad 16,17)$ shows the standard scores of each test in the battery to measure the level of skills. The researcher indicates that these standard scores belong to students of the Faculty of Physical Education in Port said

Table (6)

Z-Score \& T-Score for Stance \& foot work evaluation test $\mathrm{M}=\mathbf{5 . 8 7} \quad \mathrm{SD}=\mathbf{1 . 6 3}$

\begin{tabular}{c|c|c|c|c|c}
\hline \hline $\begin{array}{c}\text { Observation } \\
\text { Values } \\
\text { (Degree) }\end{array}$ & $\begin{array}{c}\text { Z- } \\
\text { Score }\end{array}$ & $\begin{array}{c}\text { T- } \\
\text { Score }\end{array}$ & $\begin{array}{c}\text { Observation } \\
\text { Values } \\
\text { (Degree) }\end{array}$ & $\begin{array}{c}\mathbf{Z}- \\
\text { Score }\end{array}$ & $\begin{array}{c}\text { T- } \\
\text { Score }\end{array}$ \\
\hline \hline 1.00 & -2.99 & 20 & 6.00 & 0.08 & 51 \\
\hline 2.00 & -2.37 & 26 & 7.00 & 0.69 & 57 \\
\hline 3.00 & -1.76 & 32 & 8.00 & 1.31 & 63 \\
\hline 4.00 & -1.15 & 39 & 9.00 & 1.92 & 69 \\
\hline 5.00 & -0.53 & 45 & 10.00 & 2.53 & 75 \\
\hline 5.87 & 0.00 & 50 & & & \\
\hline \hline
\end{tabular}

\section{Table (7)}

Z-Score \& T-Score for Lead hand straight punch to the head (Jab) force Test $\mathrm{M}=\mathbf{5 7 . 5 5} \quad \mathrm{SD}=\mathbf{1 3 . 3 7}$

\begin{tabular}{|c|c|c|c|c|c|c|c|c|c|c|c|}
\hline 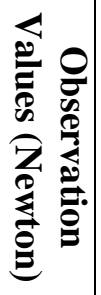 & $\begin{array}{l}\mathbf{N} \\
1 \\
\tilde{d} \\
0 \\
0 \\
0\end{array}$ & $\begin{array}{l}\overrightarrow{1} \\
\dot{1} \\
\tilde{\delta} \\
\frac{1}{0}\end{array}$ & 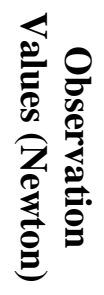 & $\begin{array}{l}\mathbf{N} \\
\hat{1} \\
0 \\
0 \\
0\end{array}$ & $\begin{array}{l}-1 \\
\dot{1} \\
\tilde{8} \\
0 \\
0\end{array}$ & 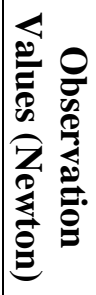 & $\begin{array}{l}\mathbf{N} \\
\text { in } \\
0 \\
0 \\
0\end{array}$ & 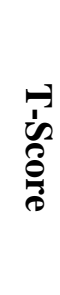 & 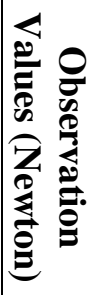 & $\begin{array}{l}N \\
\text { in } \\
0 \\
0 \\
0\end{array}$ & $\begin{array}{l}1 \\
\text { in } \\
0 \\
0 \\
0\end{array}$ \\
\hline 20 & -2.81 & 22 & 53 & -0.34 & 47 & 85 & 2.05 & 71 & 118 & 4.52 & 95 \\
\hline 21 & -2.73 & 23 & 54 & -0.27 & 47 & 86 & 2.13 & 71 & 119 & 4.60 & 96 \\
\hline 22 & -2.66 & 23 & 55 & -0.19 & 48 & 87 & 2.20 & 72 & 120 & 4.67 & 97 \\
\hline 23 & -2.58 & 24 & 56 & -0.12 & 49 & 88 & 2.28 & 73 & 121 & 4.75 & 97 \\
\hline 24 & -2.51 & 25 & 57 & -0.04 & 50 & 89 & 2.35 & 74 & 122 & 4.82 & 98 \\
\hline 25 & -2.43 & 26 & 57.55 & 0.00 & 50 & 90 & 2.43 & 74 & 123 & 4.90 & 99 \\
\hline 26 & -2.36 & 26 & 58 & 0.03 & 50 & 91 & 2.50 & 75 & 124 & 4.97 & 100 \\
\hline 27 & -2.28 & 27 & 59 & 0.11 & 51 & 92 & 2.58 & 76 & 125 & 5.04 & 100 \\
\hline 28 & -2.21 & 28 & 60 & 0.18 & 52 & 93 & 2.65 & 77 & 126 & 5.12 & 101 \\
\hline
\end{tabular}


46

Follow Table (7)

Z-Score \& T-Score for Lead hand straight punch to the head

(Jab) force Test $\mathrm{M}=\mathbf{5 7 . 5 5} \quad \mathrm{SD}=\mathbf{1 3 . 3 7}$

\begin{tabular}{|c|c|c|c|c|c|c|c|c|c|c|c|}
\hline 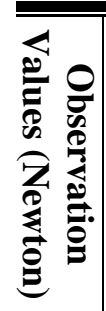 & $\begin{array}{l}N \\
\dot{y} \\
\delta \\
0 \\
0\end{array}$ & $\begin{array}{l}\text { 品 } \\
\text { ô } \\
0\end{array}$ & 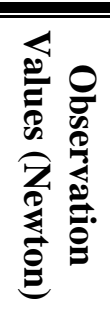 & $\begin{array}{l}N \\
\dot{d} \\
0 \\
0 \\
0\end{array}$ & 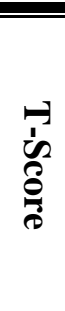 & 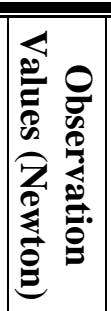 & $\begin{array}{l}N \\
\dot{1} \\
\delta \\
\frac{8}{0}\end{array}$ & $\begin{array}{l}\overrightarrow{1} \\
\dot{0} \\
\frac{8}{0} \\
0\end{array}$ & 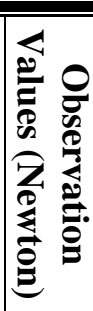 & $\begin{array}{l}N \\
\dot{d} \\
\hat{o} \\
0 \\
0\end{array}$ & \\
\hline 29 & -2.14 & 29 & & & 53 & 94 & 2.73 & 77 & 127 & 5.19 & \\
\hline 30 & & & & & & & & 78 & 128 & & \\
\hline 31 & & & & & & & & 19 & 129 & & 10. \\
\hline 32 & & & & & 55 & 97 & 2.95 & 80 & 130 & 5. & 102 \\
\hline 33 & -1.84 & & & & 56 & 98 & 3.03 & 80 & 131 & 5.49 & 105 \\
\hline 34 & -1.76 & & 6 & & 56 & 99 & 3.10 & 81 & 132 & 5.5 .5 & 106 \\
\hline 35 & -1.69 & & 6 & & 57 & 100 & 3.18 & 82 & 133 & 5.6 & 10 \\
\hline 36 & -1.61 & & 68 & & 58 & 101 & 3.25 & 82 & 134 & 5.72 & 107 \\
\hline 37 & -1.54 & & 65 & & 59 & 102 & 3.32 & 83 & 135 & 5.79 & 108 \\
\hline 38 & -1.46 & 3 & 70 & & 59 & 103 & 3.40 & 84 & 136 & 5.87 & $10 s$ \\
\hline 39 & -1.39 & 36 & 71 & & 60 & 104 & 3.47 & 85 & 137 & 5.94 & 10 \\
\hline 40 & -1.31 & 37 & 72 & & 61 & 105 & 3.55 & 85 & 138 & 6.02 & 11 \\
\hline 41 & -1.24 & 38 & 73 & & 62 & 106 & 3.62 & 86 & 139 & 6.09 & 111 \\
\hline 42 & -1.16 & 38 & 74 & & 62 & 107 & 3.70 & 87 & 140 & 6.17 & 112 \\
\hline 43 & -1.09 & 39 & 75 & & 63 & 108 & 3.77 & 88 & 141 & 6.24 & 112 \\
\hline 44 & -1 & & 1 & & & 09 & 3.85 & 88 & 142 & 0.32 & 113 \\
\hline 4 & -0.9 & 4 & 77 & & & 110 & 3.92 & 89 & 143 & & 11 \\
\hline 46 & -0.8 & 4 & 78 & & 65 & 111 & 4.00 & 90 & 144 & 6.47 & 115 \\
\hline 47 & -0.79 & 42 & 79 & & 66 & 112 & 4.07 & 91 & 145 & 6.54 & 115 \\
\hline 48 & -0.7 & 4. & 80 & & 67 & 113 & 4.15 & 91 & 146 & 6.62 & 11 \\
\hline 49 & -0.6 & 4 & 8 & & 68 & 114 & 4.22 & 92 & 147 & 6.69 & 117 \\
\hline 50 & & 4 & 8 & & 6 & 115 & & 93 & 148 & 77 & 11 \\
\hline 51 & & 4 & 8 & & 6 & 116 & & 94 & 149 & & \\
\hline 52 & -0.42 & 46 & 84 & & 70 & 117 & 4.45 & 94 & 150 & 6.91 & 11 \\
\hline
\end{tabular}

Assiut Journal For Sport Science Arts 
Table (8)

Z-Score \& T-Score for Lead hand straight punch to the head (Jab) speed of response Test $\mathrm{M}=0.71 \quad \mathrm{SD}=\mathbf{0 . 1 8}$

\begin{tabular}{c|c|c|c|c|c}
\hline $\begin{array}{c}\text { Observation } \\
\text { Values } \\
\text { (Second) }\end{array}$ & $\begin{array}{c}\text { Z- } \\
\text { Score }\end{array}$ & $\begin{array}{c}\text { T- } \\
\text { Score }\end{array}$ & $\begin{array}{c}\text { Observation } \\
\text { Values } \\
\text { (Second) }\end{array}$ & $\begin{array}{c}\text { Z- } \\
\text { Score }\end{array}$ & $\begin{array}{c}\text { T- } \\
\text { Score }\end{array}$ \\
\hline \hline 0.10 & 3.39 & 84 & 0.80 & -0.50 & 45 \\
\hline 0.20 & 2.83 & 78 & 0.90 & -1.06 & 39 \\
\hline 0.30 & 2.28 & 73 & 1.00 & -1.61 & 34 \\
\hline 0.40 & 1.72 & 67 & 1.10 & -2.17 & 28 \\
\hline 0.50 & 1.17 & 62 & 1.20 & -2.72 & 23 \\
\hline 0.60 & 0.61 & 56 & 1.30 & -3.28 & 17 \\
\hline 0.70 & 0.06 & 51 & 1.40 & -3.83 & 12 \\
\hline 0.71 & 0.00 & 50 & 1.50 & -4.39 & 6 \\
\hline \hline \multicolumn{5}{|c|}{ Table (9) }
\end{tabular}

Z-Score \& T-Score for Backhand straight punch to the head (Cross) force Test $\mathrm{M}=66.45 \mathrm{SD}=\mathbf{1 5 . 8 0}$

\begin{tabular}{|c|c|c|c|c|c|c|c|c|c|c|c|}
\hline 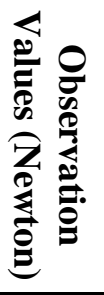 & $\begin{array}{l}\mathbf{N} \\
\text { jo } \\
\tilde{\delta} \\
\frac{1}{0}\end{array}$ & $\begin{array}{l}3 \\
\dot{1} \\
8 \\
0 \\
0\end{array}$ & 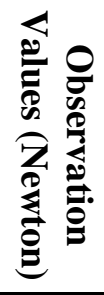 & 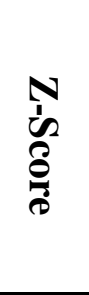 & $\begin{array}{l}\overrightarrow{1} \\
\dot{2} \\
8 \\
0 \\
0\end{array}$ & 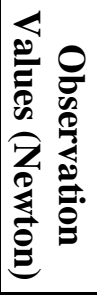 & $\begin{array}{l}\mathbf{N} \\
\dot{1} \\
\check{0} \\
0 \\
0\end{array}$ & $\begin{array}{l}\overrightarrow{1} \\
\dot{1} \\
\tilde{8} \\
0\end{array}$ & 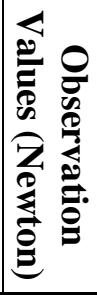 & $\begin{array}{l}\mathbf{N} \\
\dot{1} \\
\tilde{0} \\
\frac{1}{3} \\
0\end{array}$ & 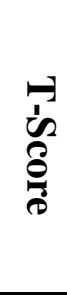 \\
\hline 20 & -2.94 & 21 & 53 & -0.85 & 41 & 85 & 1.17 & 62 & 118 & 3.26 & 83 \\
\hline 21 & -2.88 & 21 & 54 & -0.79 & 42 & 86 & 1.24 & 62 & 119 & 3.33 & 83 \\
\hline 22 & -2.81 & 22 & 55 & -0.72 & 43 & 87 & 1.30 & 63 & 120 & 3.39 & 84 \\
\hline 23 & -2.75 & 23 & 56 & -0.66 & 43 & 88 & 1.36 & 64 & 121 & 3.45 & 85 \\
\hline 24 & -2.69 & 23 & 57 & -0.60 & 44 & 89 & 1.43 & 64 & 122 & 3.52 & 85 \\
\hline 25 & -2.62 & 24 & 58 & -0.53 & 45 & 90 & 1.49 & 65 & 123 & 3.58 & 86 \\
\hline 26 & -2.56 & 24 & 59 & -0.47 & 45 & 91 & 1.55 & 66 & 124 & 3.64 & 86 \\
\hline 27 & -2.50 & 25 & 60 & -0.41 & 46 & 92 & 1.62 & 66 & 125 & 3.71 & 87 \\
\hline 28 & -2.43 & 26 & 61 & -0.34 & 47 & 93 & 1.68 & 67 & 126 & 3.77 & 88 \\
\hline 29 & -2.37 & 26 & 62 & -0.28 & 47 & 94 & 1.74 & 67 & 127 & 3.83 & 88 \\
\hline 30 & -2.31 & 27 & 63 & -0.22 & 48 & 95 & 1.81 & 68 & 128 & 3.90 & 89 \\
\hline
\end{tabular}


48

Follow Table (9)

Z-Score \& T-Score for Backhand straight punch to the head

(Cross) force Test $\mathrm{M}=\mathbf{6 6 . 4 5} \mathrm{SD}=\mathbf{1 5 . 8 0}$

\begin{tabular}{|c|c|c|c|c|c|c|c|c|c|c|c|}
\hline 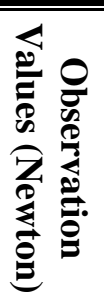 & $\begin{array}{l}\mathbf{N} \\
1 \\
\tilde{\alpha} \\
\tilde{0} \\
0\end{array}$ & $\begin{array}{l}\overrightarrow{1} \\
\dot{d} \\
\tilde{8} \\
\hat{8}\end{array}$ & 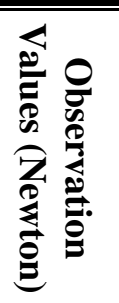 & $\begin{array}{l}\mathbf{N} \\
\hat{1} \\
\tilde{\alpha} \\
\tilde{0} \\
0 \\
0\end{array}$ & $\begin{array}{l}\overrightarrow{1} \\
\dot{1} \\
\tilde{\delta} \\
0 \\
0\end{array}$ & 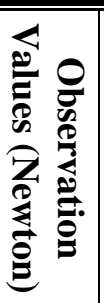 & $\begin{array}{l}\mathbf{N} \\
\hat{d} \\
\tilde{0} \\
0 \\
0\end{array}$ & 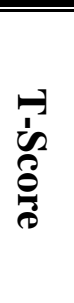 & 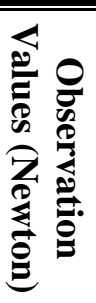 & $\begin{array}{l}\mathbf{N} \\
\text { jo } \\
\tilde{\delta} \\
0 \\
0\end{array}$ & $\begin{array}{l}\overrightarrow{1} \\
\dot{\alpha} \\
\tilde{\delta} \\
\dot{0}\end{array}$ \\
\hline 31 & -2.24 & 28 & 64 & -0.16 & 48 & 96 & 1.87 & 69 & 129 & 3.96 & 90 \\
\hline 32 & -2.18 & 28 & 65 & -0.09 & 49 & 97 & 1.93 & 69 & 130 & 4.02 & 90 \\
\hline 33 & -2.12 & 29 & 66 & -0.03 & 50 & 98 & 2.00 & 70 & 131 & 4.09 & 91 \\
\hline 34 & -2.05 & 29 & 66.45 & 0.00 & 50 & 99 & 2.06 & 71 & 132 & 4.15 & 91 \\
\hline 35 & -1.99 & 30 & 67 & 0.03 & 50 & 100 & 2.12 & 71 & 133 & 4.21 & 92 \\
\hline 36 & -1.93 & 31 & 68 & 0.10 & 51 & 101 & 2.19 & 72 & 134 & 4.28 & 93 \\
\hline 37 & -1.86 & 31 & 69 & 0.16 & 52 & 102 & 2.25 & 73 & 135 & 4.34 & 93 \\
\hline 38 & -1.80 & 32 & 70 & 0.22 & 52 & 103 & 2.31 & 73 & 136 & 4.40 & 94 \\
\hline 39 & -1.74 & 33 & 71 & 0.29 & 53 & 104 & 2.38 & 74 & 137 & 4.47 & 95 \\
\hline 40 & -1.67 & 33 & 72 & 0.35 & 54 & 105 & 2.44 & 74 & 138 & 4.53 & 95 \\
\hline 41 & -1.61 & 34 & 73 & 0.41 & 54 & 106 & 2.50 & 75 & 139 & 4.59 & 96 \\
\hline 42 & -1.55 & 35 & & 0.48 & 55 & 107 & 2.57 & 76 & 140 & 4.66 & 97 \\
\hline 43 & -1.48 & 35 & 75 & 0.54 & 55 & 108 & 2.63 & 76 & 141 & 4.72 & 97 \\
\hline 44 & -1.42 & 36 & 76 & 0.60 & 56 & 109 & 2.69 & 77 & 142 & 4.78 & 98 \\
\hline 45 & -1.36 & 36 & 77 & 0.67 & 57 & 110 & 2.76 & 78 & 143 & 4.84 & 98 \\
\hline 46 & -1.29 & 37 & 78 & 0.73 & 57 & 111 & 2.82 & 78 & 144 & 4.91 & 99 \\
\hline 47 & -1.23 & 38 & 79 & 0.79 & 58 & 112 & 2.88 & 79 & 145 & 4.97 & 100 \\
\hline 48 & -1.17 & 38 & 80 & 0.86 & 59 & 113 & 2.95 & 79 & 146 & 5.03 & 100 \\
\hline 49 & -1.10 & 39 & 81 & 0.92 & 59 & 114 & 3.01 & 80 & 147 & 5.10 & 101 \\
\hline 50 & -1.04 & 40 & 82 & 0.98 & 60 & 115 & 3.07 & 81 & 148 & 5.16 & 102 \\
\hline 51 & -0.98 & 40 & 83 & 1.05 & 60 & 116 & 3.14 & 81 & 149 & 5.22 & 102 \\
\hline 52 & -0.91 & 41 & 84 & 1.11 & 61 & 117 & 3.20 & 82 & 150 & 5.29 & 103 \\
\hline
\end{tabular}

Assiut Journal For Sport Science Arts 
Table (10)

Z-Score \& T-Score for Backhand straight punch to the head (Cross) speed of response Test $\mathrm{M}=.71 \quad \mathrm{SD}=.20$

\begin{tabular}{c|c|c|c|c|c}
\hline $\begin{array}{c}\text { Observation } \\
\text { Values } \\
\text { (Second) }\end{array}$ & $\begin{array}{c}\text { Z- } \\
\text { Score }\end{array}$ & $\begin{array}{c}\text { T- } \\
\text { Score }\end{array}$ & $\begin{array}{c}\text { Observation } \\
\text { Values } \\
\text { (Second) }\end{array}$ & $\begin{array}{c}\text { Z- } \\
\text { Score }\end{array}$ & $\begin{array}{c}\text { T- } \\
\text { Score }\end{array}$ \\
\hline \hline 0.10 & 3.05 & 81 & 0.80 & -0.45 & 46 \\
\hline 0.20 & 2.55 & 76 & 0.90 & -0.95 & 41 \\
\hline 0.30 & 2.05 & 71 & 1.00 & -1.45 & 36 \\
\hline 0.40 & 1.55 & 66 & 1.10 & -1.95 & 31 \\
\hline 0.50 & 1.05 & 61 & 1.20 & -2.45 & 26 \\
\hline 0.60 & 0.55 & 56 & 1.30 & -2.95 & 21 \\
\hline 0.70 & 0.05 & 51 & 1.40 & -3.45 & 16 \\
\hline 0.71 & 0.00 & 50 & 1.50 & -3.95 & 11 \\
\hline \hline
\end{tabular}

Table (11)

Z-Score \& T-Score for Lead hand straight punch to the body (Jab) force Test $M=63.71 \quad S D=19.95$

\begin{tabular}{|c|c|c|c|c|c|c|c|c|c|c|c|}
\hline 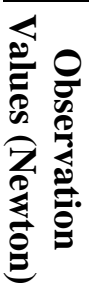 & $\begin{array}{l}\mathbf{N} \\
\dot{d} \\
\tilde{\delta} \\
\tilde{\delta} \\
0\end{array}$ & $\begin{array}{l}\overrightarrow{1} \\
\dot{\phi} \\
\tilde{\delta} \\
\dot{0}\end{array}$ & 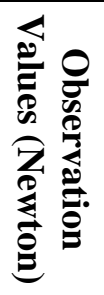 & 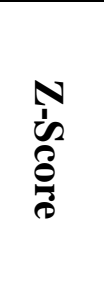 & $\begin{array}{l}\overrightarrow{1} \\
\dot{1} \\
\tilde{0} \\
0\end{array}$ & 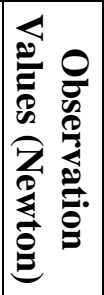 & 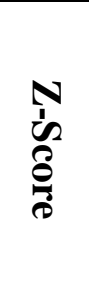 & $\begin{array}{l}\overrightarrow{1} \\
\dot{1} \\
\dot{0}\end{array}$ & 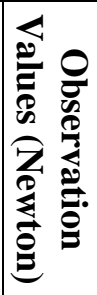 & 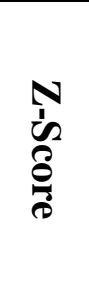 & $\begin{array}{l}-1 \\
\dot{1} \\
8 \\
0 \\
0\end{array}$ \\
\hline 20 & -2.19 & 28 & 53 & -0.54 & 45 & 85 & 1.07 & 61 & 118 & 2.72 & 77 \\
\hline 21 & -2.14 & 29 & 54 & -0.49 & 45 & 86 & 1.12 & 61 & 119 & 2.77 & 78 \\
\hline 22 & -2.09 & 29 & 55 & -0.44 & 46 & 87 & 1.17 & 62 & 120 & 2.82 & 78 \\
\hline 23 & -2.04 & 30 & 56 & -0.39 & 46 & 88 & 1.22 & 62 & 121 & 2.87 & 79 \\
\hline 24 & -1.99 & 30 & 57 & -0.34 & 47 & 89 & 1.27 & 63 & 122 & 2.92 & 79 \\
\hline 25 & -1.94 & 31 & 58 & -0.29 & 47 & 90 & 1.32 & 63 & 123 & 2.97 & 80 \\
\hline 26 & -1.89 & 31 & 59 & -0.24 & 48 & 91 & 1.37 & 64 & 124 & 3.02 & 80 \\
\hline 27 & -1.84 & 32 & 60 & -0.19 & 48 & 92 & 1.42 & 64 & 125 & 3.07 & 81 \\
\hline 28 & -1.79 & 32 & 61 & -0.14 & 49 & 93 & 1.47 & 65 & 126 & 3.12 & 81 \\
\hline 29 & -1.74 & 33 & 62 & -0.09 & 49 & 94 & 1.52 & 65 & 127 & 3.17 & 82 \\
\hline 30 & -1.69 & 33 & 63 & -0.04 & 50 & 95 & 1.57 & 66 & 128 & 3.22 & 82 \\
\hline
\end{tabular}


50

Table (11)

Z-Score \& T-Score for Lead hand straight punch to the body (Jab) force Test $\mathrm{M}=63.71 \quad \mathrm{SD}=19.95$

\begin{tabular}{|c|c|c|c|c|c|c|c|c|c|c|c|}
\hline 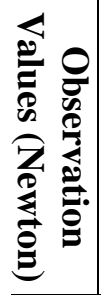 & 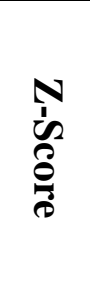 & $\begin{array}{l}\overrightarrow{1} \\
\dot{d} \\
\check{0} \\
\frac{0}{0}\end{array}$ & 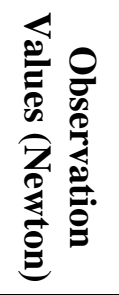 & $\begin{array}{l}\mathbf{N} \\
\dot{1} \\
\stackrel{2}{0} \\
0 \\
0\end{array}$ & $\begin{array}{l}1 \\
\dot{1} \\
\stackrel{2}{0} \\
0 \\
0\end{array}$ & 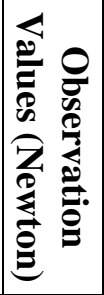 & $\begin{array}{l}N \\
\dot{1} \\
\tilde{0} \\
0 \\
0\end{array}$ & $\begin{array}{l}1 \\
\dot{1} \\
\ddot{0} \\
0\end{array}$ & 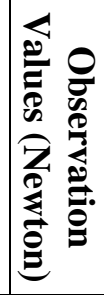 & $\begin{array}{l}N \\
\mathbf{1} \\
\tilde{\delta} \\
\vdots \\
0\end{array}$ & $\begin{array}{l}1 \\
\dot{1} \\
8 \\
0 \\
0\end{array}$ \\
\hline 31 & -1.64 & 34 & 63.71 & 0.00 & 50 & 96 & 1.62 & 66 & 129 & 3.27 & 83 \\
\hline 32 & -1.59 & 34 & 64 & 0.01 & 50 & 97 & 1.67 & 67 & 130 & 3.32 & 83 \\
\hline 33 & -1.54 & 35 & 65 & 0.06 & 51 & 98 & 1.72 & 67 & 131 & 3.37 & 84 \\
\hline 34 & -1.49 & 35 & 66 & 0.11 & 51 & 99 & 1.77 & 68 & 132 & 3.42 & 84 \\
\hline 35 & -1.44 & 36 & 67 & 0.16 & 52 & 100 & 1.82 & 68 & 133 & 3.47 & 85 \\
\hline 36 & -1.39 & 36 & 68 & 0.22 & 52 & 101 & 1.87 & 69 & 134 & 3.52 & 85 \\
\hline 37 & -1.34 & 37 & 69 & 0.27 & 53 & 102 & 1.92 & 69 & 135 & 3.57 & 86 \\
\hline 38 & -1.29 & 37 & 70 & 0.32 & 53 & 103 & 1.97 & 70 & 136 & 3.62 & 86 \\
\hline 39 & -1.24 & 38 & 71 & 0.37 & 54 & 104 & 2.02 & 70 & 137 & 3.67 & 87 \\
\hline 40 & -1.19 & 38 & 72 & 0.42 & 54 & 105 & 2.07 & 71 & 138 & 3.72 & 87 \\
\hline 41 & -1.14 & 39 & 73 & 0.47 & 55 & 106 & 2.12 & 71 & 139 & 3.77 & 88 \\
\hline 42 & -1.09 & 39 & 74 & 0.52 & 55 & 107 & 2.17 & 72 & 140 & 3.82 & 88 \\
\hline 43 & -1.04 & 40 & 75 & 0.57 & 56 & 108 & 2.22 & 72 & 141 & 3.87 & 89 \\
\hline 44 & -0.99 & 40 & 76 & 0.62 & 56 & 109 & 2.27 & 73 & 142 & 3.92 & 89 \\
\hline 45 & -0.94 & 41 & 77 & 0.67 & 57 & 110 & 2.32 & 73 & 143 & 3.97 & 90 \\
\hline 46 & -0.89 & 41 & 78 & 0.72 & 57 & 111 & 2.37 & 74 & 144 & 4.02 & 90 \\
\hline 47 & -0.84 & 42 & 79 & 0.77 & 58 & 112 & 2.42 & 74 & 145 & 4.07 & 91 \\
\hline 48 & -0.79 & 42 & 80 & 0.82 & 58 & 113 & 2.47 & 75 & 146 & 4.12 & 91 \\
\hline 49 & -0.74 & 43 & 81 & 0.87 & 59 & 114 & 2.52 & 75 & 147 & 4.17 & 92 \\
\hline 50 & -0.69 & 43 & 82 & 0.92 & 59 & 115 & 2.57 & 76 & 148 & 4.23 & 92 \\
\hline 51 & -0.64 & 44 & 83 & 0.97 & 60 & 116 & 2.62 & 76 & 149 & 4.28 & 93 \\
\hline 52 & -0.59 & 44 & 84 & 1.02 & 60 & 117 & 2.67 & 77 & 150 & 4.33 & 93 \\
\hline
\end{tabular}

Assiut Journal For Sport Science Arts 
Table (12)

Z-Score \& T-Score for Lead hand straight punch to the body (Jab) speed of response Test $\mathrm{M}=.65 \quad \mathrm{SD}=.20$

\begin{tabular}{c|c|c|c|c|c}
\hline $\begin{array}{c}\text { Observation } \\
\text { Values } \\
\text { (Second) }\end{array}$ & $\begin{array}{c}\text { Z- } \\
\text { Score }\end{array}$ & $\begin{array}{c}\text { T- } \\
\text { Score }\end{array}$ & $\begin{array}{c}\text { Observation } \\
\text { Values } \\
\text { (Second) }\end{array}$ & $\begin{array}{c}\text { Z- } \\
\text { Score }\end{array}$ & $\begin{array}{c}\text { T- } \\
\text { Score }\end{array}$ \\
\hline \hline 0.10 & 2.75 & 78 & 0.71 & -0.30 & 47 \\
\hline 0.20 & 2.25 & 73 & 0.80 & -0.75 & 43 \\
\hline 0.30 & 1.75 & 68 & 0.90 & -1.25 & 38 \\
\hline 0.40 & 1.25 & 63 & 1.00 & -1.75 & 33 \\
\hline 0.50 & 0.75 & 58 & 1.10 & -2.25 & 28 \\
\hline 0.60 & 0.25 & 53 & 1.20 & -2.75 & 23 \\
\hline 0.65 & 0.00 & 50 & 1.30 & -3.25 & 18 \\
\hline 0.68 & -0.15 & 49 & 1.40 & -3.75 & 13 \\
\hline 0.70 & -0.25 & 48 & 1.50 & -4.25 & 8 \\
\hline \hline
\end{tabular}

Table (13)

Z-Score \& T-Score for Backhand straight punch to the body (Cross) force Test $\mathrm{M}=\mathbf{6 9 . 0 0} \mathrm{SD}=19.02$

\begin{tabular}{|c|c|c|c|c|c|c|c|c|c|c|c|}
\hline 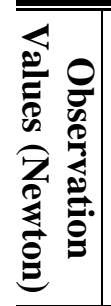 & $\begin{array}{l}N \\
\text { d. } \\
\delta \\
\vdots \\
0\end{array}$ & 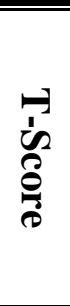 & 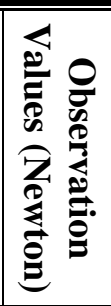 & $\begin{array}{l}N \\
\hat{d} \\
0 \\
0 \\
0\end{array}$ & 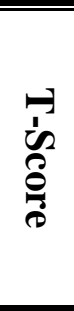 & 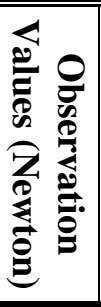 & 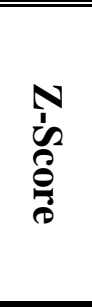 & $\begin{array}{l}1 \\
1 \\
\dot{b} \\
0 \\
0 \\
0 \\
0\end{array}$ & 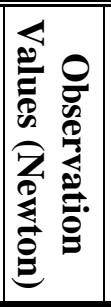 & $\begin{array}{l}N \\
\text { in } \\
\delta \\
0 \\
0 \\
0\end{array}$ & ¿2 \\
\hline 20 & -2.58 & & 53 & & 42 & 86 & & 59 & 119 & 2.63 & \\
\hline 21 & -2 & & 54 & & & & & 9 & 120 & & \\
\hline 22 & & & 55 & & & & & 60 & 121 & & \\
\hline 23 & -2.42 & & 56 & & 13 & & .05 & 61 & 122 & 2.79 & 8 \\
\hline 24 & -2.37 & & 57 & 0.63 & & 90 & .10 & 61 & 123 & 2.84 & 8 \\
\hline 25 & -2.31 & 2 & 58 & .58 & 44 & 91 & 1.16 & 62 & 124 & 2.89 & $\overline{9}$ \\
\hline 26 & -2.26 & $\frac{2}{2}$ & 59 & 0.5 & & & & 6 & 12 & 2.9 & \\
\hline 27 & -2.2 & & 60 & & & & & 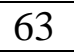 & 126 & 3.00 & \\
\hline 28 & -2.1 & 2 & 61 & & 4 & 94 & 1.31 & 63 & 127 & 3.05 & 30 \\
\hline 29 & -2.1 & 29 & 62 & & 46 & 95 & 1.37 & 64 & 128 & 3.10 & \\
\hline
\end{tabular}

Assiut Journal For Sport Science Arts 


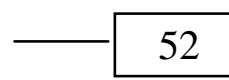

Follow Table (13)

Z-Score \& T-Score for Backhand straight punch to the body (Cross) force Test $M=69.00 \quad S D=19.02$

\begin{tabular}{|c|c|c|c|c|c|c|c|c|c|c|c|}
\hline 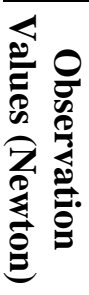 & $\begin{array}{l}\mathbf{N} \\
\hat{1} \\
\tilde{\alpha} \\
\hat{\delta} \\
0\end{array}$ & $\begin{array}{l}\overrightarrow{1} \\
\dot{1} \\
\tilde{0} \\
0\end{array}$ & 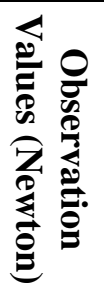 & $\begin{array}{l}\mathbf{N} \\
\mathbf{1} \\
\tilde{0} \\
\vdots \\
0\end{array}$ & 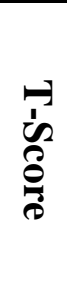 & 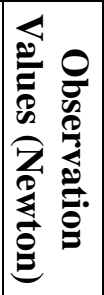 & 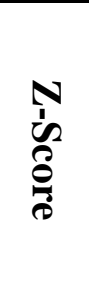 & 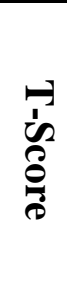 & 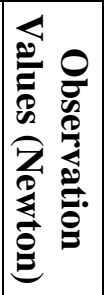 & 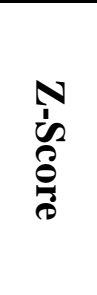 & $\begin{array}{l}1 \\
\text { फे } \\
0 \\
0 \\
0\end{array}$ \\
\hline 30 & -2.05 & 29 & 63 & -0.32 & 47 & 96 & 1.42 & 64 & 129 & 3.15 & 82 \\
\hline 31 & -2.00 & 30 & 64 & -0.26 & 47 & 97 & 1.47 & 65 & 130 & 3.21 & 82 \\
\hline 32 & -1.95 & 31 & 65 & -0.21 & 48 & 98 & 1.52 & 65 & 131 & 3.26 & 83 \\
\hline 33 & -1.89 & 31 & 66 & -0.16 & 48 & 99 & 1.58 & 66 & 132 & 3.31 & 83 \\
\hline 34 & -1.84 & 32 & 67 & -0.11 & 49 & 100 & 1.63 & 66 & 133 & 3.36 & 84 \\
\hline 35 & -1.79 & 32 & 68 & -0.05 & 49 & 101 & 1.68 & 67 & 134 & 3.42 & 84 \\
\hline 36 & -1.74 & 33 & 69 & 0.00 & 50 & 102 & 1.74 & 67 & 135 & 3.47 & 85 \\
\hline 37 & -1.68 & 33 & 70 & 0.05 & 51 & 103 & 1.79 & 68 & 136 & 3.52 & 85 \\
\hline 38 & -1.63 & 34 & 71 & 0.11 & 51 & 104 & 1.84 & 68 & 137 & 3.58 & 86 \\
\hline 39 & -1.58 & 34 & 72 & 0.16 & 52 & 105 & 1.89 & 69 & 138 & 3.63 & 86 \\
\hline 40 & -1.52 & 35 & 73 & 0.21 & 52 & 106 & 1.95 & 69 & 139 & 3.68 & 87 \\
\hline 41 & -1.47 & 35 & 74 & 0.26 & 53 & 107 & 2.00 & 70 & 140 & 3.73 & 87 \\
\hline 42 & -1.42 & 36 & 75 & 0.32 & 53 & 108 & 2.05 & 71 & 141 & 3.79 & 88 \\
\hline 43 & -1.37 & 36 & 76 & 0.37 & 54 & 109 & 2.10 & 71 & 142 & 3.84 & 88 \\
\hline 44 & -1.31 & 37 & 77 & 0.42 & 54 & 110 & 2.16 & 72 & 143 & 3.89 & 89 \\
\hline 45 & -1.26 & 37 & 78 & 0.47 & 55 & 111 & 2.21 & 72 & 144 & 3.94 & 89 \\
\hline 46 & -1.21 & 38 & 79 & 0.53 & 55 & 112 & 2.26 & 73 & 145 & 4.00 & 90 \\
\hline 47 & -1.16 & 38 & 80 & 0.58 & 56 & 113 & 2.31 & 73 & 146 & 4.05 & 90 \\
\hline 48 & -1.10 & 39 & 81 & 0.63 & 56 & 114 & 2.37 & 74 & 147 & 4.10 & 91 \\
\hline 49 & -1.05 & 39 & 82 & 0.68 & 57 & 115 & 2.42 & 74 & 148 & 4.15 & 92 \\
\hline 50 & -1.00 & 40 & 83 & 0.74 & 57 & 116 & 2.47 & 75 & 149 & 4.21 & 92 \\
\hline 51 & -0.95 & 41 & 84 & 0.79 & 58 & 117 & 2.52 & 75 & 150 & 4.26 & 93 \\
\hline 52 & -0.89 & 41 & 85 & 0.84 & 58 & 118 & 2.58 & 76 & & & \\
\hline
\end{tabular}


Table (14)

Z-Score \& T-Score for Backhand straight punch to the body (Cross) speed of response Test $\mathrm{M}=\mathbf{0 . 6 8} \quad \mathrm{SD}=.14$

\begin{tabular}{c|c|c|c|c|c}
\hline $\begin{array}{c}\text { Observation } \\
\text { Values } \\
\text { (Second) }\end{array}$ & $\begin{array}{c}\text { Z- } \\
\text { Score }\end{array}$ & $\begin{array}{c}\text { T- } \\
\text { Score }\end{array}$ & $\begin{array}{c}\text { Observation } \\
\text { Values } \\
\text { (Second) }\end{array}$ & $\begin{array}{c}\text { Z- } \\
\text { Score }\end{array}$ & $\begin{array}{c}\text { T- } \\
\text { Score }\end{array}$ \\
\hline \hline 0.10 & 4.14 & 91 & 0.71 & -0.21 & 48 \\
\hline 0.20 & 3.43 & 84 & 0.80 & -0.86 & 41 \\
\hline 0.30 & 2.71 & 77 & 0.90 & -1.57 & 34 \\
\hline 0.40 & 2.00 & 70 & 1.00 & -2.29 & 27 \\
\hline 0.50 & 1.29 & 63 & 1.10 & -3.00 & 20 \\
\hline 0.60 & 0.57 & 56 & 1.20 & -3.71 & 13 \\
\hline 0.65 & 0.21 & 52 & 1.30 & -4.43 & 6 \\
\hline 0.68 & 0.00 & 50 & 1.40 & -5.14 & -1 \\
\hline 0.70 & -0.14 & 49 & 1.50 & -5.86 & -9 \\
\hline \hline
\end{tabular}

Table (15)

Z-Score \& T-Score for the speed of Jab-cross combination punches in the 30th test $\mathrm{M}=\mathbf{5 9 . 4 0} \quad \mathrm{SD}=\mathbf{1 5 . 4 5}$

\begin{tabular}{|c|c|c|c|c|c|c|c|c|c|c|c|}
\hline 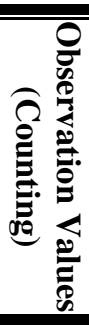 & $\begin{array}{l}\mathbf{N} \\
\text { ஸे } \\
\tilde{0} \\
0\end{array}$ & $\begin{array}{l}1 \\
\dot{1} \\
0 \\
0 \\
0 \\
0\end{array}$ & 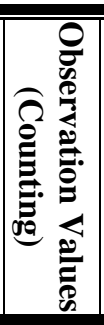 & 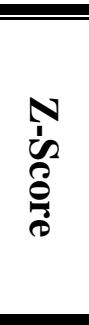 & $\begin{array}{l}\overrightarrow{1} \\
\dot{1} \\
\tilde{0} \\
\dot{0}\end{array}$ & 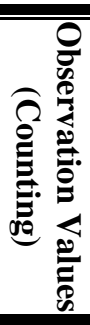 & 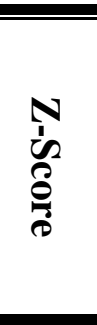 & 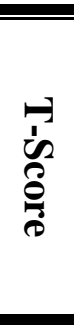 & 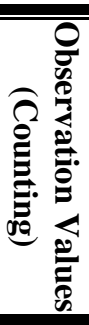 & $\begin{array}{l}\mathbf{N} \\
\mathbf{1} \\
0 \\
0 \\
0 \\
0\end{array}$ & $\begin{array}{l}9 \\
\dot{1} \\
8 \\
\frac{8}{8}\end{array}$ \\
\hline 30 & -1.90 & 31 & 60 & 0.04 & 50 & 91 & 2.05 & 70 & 122 & 4.05 & 91 \\
\hline 31 & -1.84 & 32 & 61 & 0.10 & 51 & 92 & 2.11 & 71 & 123 & 4.12 & 91 \\
\hline 32 & -1.77 & 32 & 62 & 0.17 & 52 & 93 & 2.17 & 72 & 124 & 4.18 & 92 \\
\hline 33 & -1.71 & 33 & 63 & 0.23 & 52 & 94 & 2.24 & 72 & 125 & 4.25 & 92 \\
\hline 34 & -1.64 & 34 & 64 & 0.30 & 53 & 95 & 2.30 & 73 & 126 & 4.31 & 93 \\
\hline 35 & -1.58 & 34 & 65 & 0.36 & 54 & 96 & 2.37 & 74 & 127 & 4.38 & 94 \\
\hline 36 & -1.51 & 35 & 66 & 0.43 & 54 & 97 & 2.43 & 74 & 128 & 4.44 & 94 \\
\hline 37 & -1.45 & 36 & 67 & 0.49 & 55 & 98 & 2.50 & 75 & 129 & 4.50 & 95 \\
\hline 38 & -1.39 & 36 & 68 & 0.56 & 56 & 99 & 2.56 & 76 & 130 & 4.57 & 96 \\
\hline 39 & -1.32 & 37 & 69 & 0.62 & 56 & 100 & 2.63 & 76 & 131 & 4.63 & 96 \\
\hline
\end{tabular}


Follow Table (15)

Z-Score \& T-Score for the speed of Jab-cross combination punches in the 30th test $M=59.40$

$\mathrm{SD}=15.45$

\begin{tabular}{|c|c|c|c|c|c|c|c|c|c|c|c|}
\hline 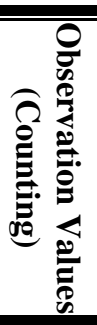 & $\begin{array}{l}\mathbf{N} \\
\mathbf{1} \\
\tilde{\alpha} \\
0 \\
0\end{array}$ & $\begin{array}{l}1 \\
\dot{1} \\
\stackrel{2}{0} \\
\frac{0}{0}\end{array}$ & 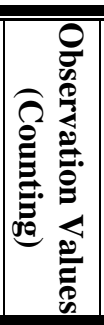 & 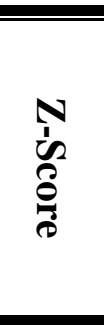 & $\begin{array}{l}\overrightarrow{1} \\
\dot{1} \\
\tilde{0} \\
\dot{0}\end{array}$ & 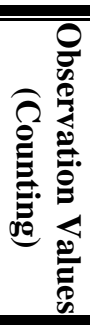 & $\begin{array}{l}\mathbf{N} \\
1 \\
\tilde{L} \\
\vdots \\
0 \\
0\end{array}$ & $\begin{array}{l}\overrightarrow{1} \\
\dot{1} \\
0 \\
0 \\
0\end{array}$ & 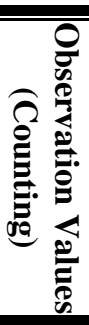 & $\begin{array}{l}\mathbf{N} \\
\text { jo } \\
0 \\
0 \\
0\end{array}$ & $\begin{array}{l}1 \\
\dot{1} \\
0 \\
0 \\
0\end{array}$ \\
\hline 40 & -1.26 & 37 & 70 & 0.69 & 57 & 101 & 2.69 & 77 & 132 & 4.70 & 97 \\
\hline 41 & -1.19 & 38 & 71 & 0.75 & 58 & 102 & 2.76 & 78 & 133 & 4.76 & 98 \\
\hline 42 & -1.13 & 39 & 72 & 0.82 & 58 & 103 & 2.82 & 78 & 134 & 4.83 & 98 \\
\hline 43 & -1.06 & 39 & 73 & 0.88 & 59 & 104 & 2.89 & 79 & 135 & 4.89 & 99 \\
\hline 44 & -1.00 & 40 & 74 & 0.94 & 59 & 105 & 2.95 & 80 & 136 & 4.96 & 100 \\
\hline 45 & -0.93 & 41 & 75 & 1.01 & 60 & 106 & 3.02 & 80 & 137 & 5.02 & 100 \\
\hline 46 & -0.87 & 41 & 76 & 1.07 & 61 & 107 & 3.08 & 81 & 138 & 5.09 & 101 \\
\hline 47 & -0.80 & 42 & 77 & 1.14 & 61 & 108 & 3.15 & 81 & 139 & 5.15 & 102 \\
\hline 48 & -0.74 & 43 & 78 & 1.20 & 62 & 109 & 3.21 & 82 & 140 & 5.22 & 102 \\
\hline 49 & -0.67 & 43 & 79 & 1.27 & 63 & 110 & 3.28 & 83 & 141 & 5.28 & 103 \\
\hline 50 & -0.61 & 44 & 80 & 1.33 & 63 & 111 & 3.34 & 83 & 142 & 5.35 & 103 \\
\hline 51 & -0.54 & 45 & 81 & 1.40 & 64 & 112 & 3.40 & 84 & 143 & 5.41 & 104 \\
\hline 52 & -0.48 & 45 & 82 & 1.46 & 65 & 113 & 3.47 & 85 & 144 & 5.48 & 105 \\
\hline 53 & -0.41 & 46 & 83 & 1.53 & 65 & 114 & 3.53 & 85 & 145 & 5.54 & 105 \\
\hline 54 & -0.35 & 47 & 84 & 1.59 & 66 & 115 & 3.60 & 86 & 146 & 5.61 & 106 \\
\hline 55 & -0.28 & 47 & 85 & 1.66 & 67 & 116 & 3.66 & 87 & 147 & 5.67 & 107 \\
\hline 56 & -0.22 & 48 & 86 & 1.72 & 67 & 117 & 3.73 & 87 & 148 & 5.73 & 107 \\
\hline 57 & -0.16 & 48 & 87 & 1.79 & 68 & 118 & 3.79 & 88 & 149 & 5.80 & 108 \\
\hline 58 & -0.09 & 49 & 88 & 1.85 & 69 & 119 & 3.86 & 89 & 150 & 5.86 & 109 \\
\hline 59 & -0.03 & 50 & 89 & 1.92 & 69 & 120 & 3.92 & 89 & & & \\
\hline 59.4 & 0.00 & 50 & 90 & 1.98 & 70 & 121 & 3.99 & 90 & & & \\
\hline
\end{tabular}

Assiut Journal For Sport Science Arts 
Table (16)

Z-Score \& T-Score for the speed of one Jab-cross combination punches test $\mathrm{M}=.21 \quad \mathrm{SD}=.07$

\begin{tabular}{|c|c|c|c|c|c|}
\hline 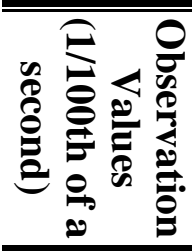 & \begin{tabular}{l}
$\mathbf{N}$ \\
$\vdots$ \\
\multicolumn{1}{c}{} \\
0 \\
0 \\
0
\end{tabular} & $\begin{array}{l}\overrightarrow{1} \\
\dot{1} \\
\tilde{0} \\
0 \\
0\end{array}$ & 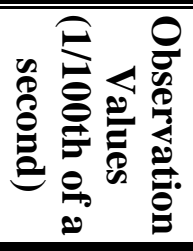 & $\begin{array}{l}\mathbf{N} \\
\dot{1} \\
0 \\
0 \\
0\end{array}$ & $\begin{array}{l}\overrightarrow{1} \\
\dot{b} \\
\tilde{\delta} \\
\frac{1}{0}\end{array}$ \\
\hline 0.10 & 1.71 & 67 & 0.26 & -0.57 & 44 \\
\hline 0.11 & 1.57 & 66 & 0.27 & -0.71 & 43 \\
\hline 0.12 & 1.43 & 64 & 0.28 & -0.86 & 41 \\
\hline 0.13 & 1.29 & 63 & 0.29 & -1.00 & 40 \\
\hline 0.14 & 1.14 & 61 & 0.30 & -1.14 & 39 \\
\hline 0.15 & 1.00 & 60 & 0.31 & -1.29 & 37 \\
\hline 0.16 & 0.86 & 59 & 0.32 & -1.43 & 36 \\
\hline 0.17 & 0.71 & 57 & 0.33 & -1.57 & 34 \\
\hline 0.18 & 0.57 & 56 & 0.34 & -1.71 & 33 \\
\hline 0.19 & 0.43 & 54 & 0.35 & -1.86 & 31 \\
\hline 0.20 & 0.29 & 53 & 0.36 & -2.00 & 30 \\
\hline 0.21 & 0.14 & 51 & 0.37 & -2.14 & 29 \\
\hline 0.22 & 0.00 & 50 & 0.38 & -2.29 & 27 \\
\hline 0.23 & -0.14 & 49 & 0.39 & -2.43 & 26 \\
\hline 0.24 & -0.29 & 47 & 0.40 & -2.57 & 24 \\
\hline 0.25 & -0.43 & 46 & & & \\
\hline
\end{tabular}

\section{Table (17)}

Z-Score \& T-Score for the speed of one cross-jab combination punches test $\mathrm{M}=.21 \quad \mathrm{SD}=.05$

\begin{tabular}{|c|c|c|c|c|c|}
\hline 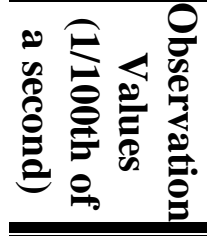 & 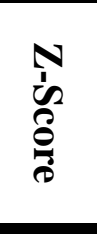 & $\begin{array}{l}\overrightarrow{1} \\
\dot{1} \\
\stackrel{0}{0} \\
0\end{array}$ & 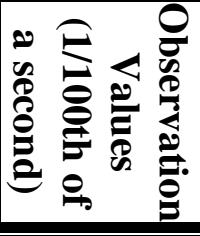 & $\begin{array}{l}\mathbf{N} \\
\text { ஸे } \\
0 \\
0 \\
0\end{array}$ & 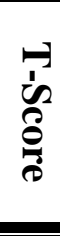 \\
\hline 0.10 & 2.20 & 72 & 0.26 & -1.00 & 40 \\
\hline 0.11 & 2.00 & 70 & 0.27 & -1.20 & 38 \\
\hline 0.12 & 1.80 & 68 & 0.28 & -1.40 & 36 \\
\hline 0.13 & 1.60 & 66 & 0.29 & -1.60 & 34 \\
\hline
\end{tabular}




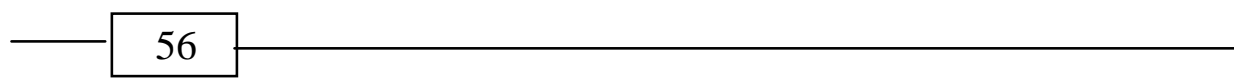

Follow Table (17)

Z-Score \& T-Score for the speed of one cross-jab combination punches test $\mathrm{M}=.21 \quad \mathrm{SD}=.05$

\begin{tabular}{|c|c|c|c|c|c|}
\hline 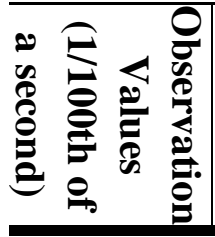 & $\begin{array}{l}\mathbf{N} \\
1 \\
0 \\
0 \\
0 \\
0\end{array}$ & $\begin{array}{l}\overrightarrow{1} \\
\dot{1} \\
\stackrel{0}{0} \\
0\end{array}$ & 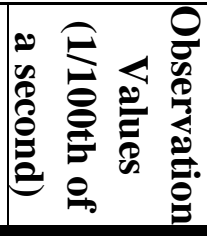 & $\begin{array}{l}\mathbf{N} \\
\text { ஸे } \\
\tilde{0} \\
0\end{array}$ & $\begin{array}{l}\overrightarrow{1} \\
\dot{1} \\
0 \\
0 \\
0\end{array}$ \\
\hline 0.14 & 1.40 & 64 & 0.30 & -1.80 & 32 \\
\hline 0.15 & 1.20 & 62 & 0.31 & -2.00 & 30 \\
\hline 0.16 & 1.00 & 60 & 0.32 & -2.20 & 28 \\
\hline 0.17 & 0.80 & 58 & 0.33 & -2.40 & 26 \\
\hline 0.18 & 0.60 & 56 & 0.34 & -2.60 & 24 \\
\hline 0.19 & 0.40 & 54 & 0.35 & -2.80 & 22 \\
\hline 0.20 & 0.20 & 52 & 0.36 & -3.00 & 20 \\
\hline 0.21 & 0.00 & 50 & 0.37 & -3.20 & 18 \\
\hline 0.22 & -0.20 & 48 & 0.38 & -3.40 & 16 \\
\hline 0.23 & -0.40 & 46 & 0.39 & -3.60 & 14 \\
\hline 0.24 & -0.60 & 44 & 0.40 & -3.80 & 12 \\
\hline 0.25 & -0.80 & 42 & & & \\
\hline
\end{tabular}

6- Present the results of the second question "What are the standard levels of performance skill to interpret the summative standard score that a student had obtained from testing battery in boxing for students at Faculty of Physical Education in Port Said?"

To answer this question, the researcher sums the T-Score for each student to get the summative standard score. This summative score represents a level of skills of the individual. Table (18) shows the minimum value, maximum value, the mean and the standard deviation of summative standard score obtained by respondents from the application of extracting testing battery. 
Table (18)

Descriptive Statistics for Boxing skill level (Sum of Standard Scores)

\begin{tabular}{|c|c|c|c|c|c|c|c|c|}
\hline \multirow{2}{*}{\multicolumn{2}{|c|}{ Variables }} & \multirow{3}{*}{ 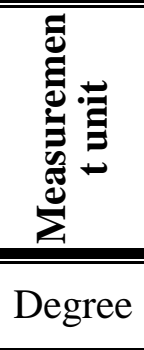 } & \multirow{3}{*}{ 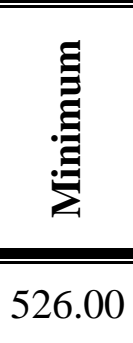 } & \multirow{3}{*}{ 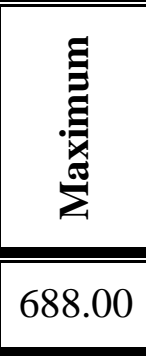 } & \multirow{3}{*}{ 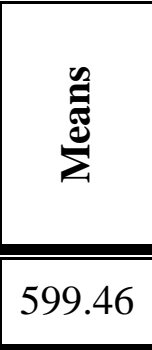 } & \multirow{3}{*}{$\frac{\text { 是 }}{33.18}$} & \multicolumn{2}{|c|}{ "Skewness } \\
\hline & & & & & & & \multirow{2}{*}{ 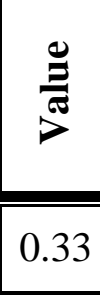 } & \multirow{2}{*}{ 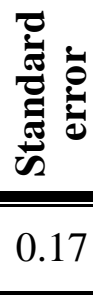 } \\
\hline 1 & & & & & & & & \\
\hline \multicolumn{4}{|c|}{$\begin{array}{l}\text { Table (18) shows that } \\
\text { the summative standard score } \\
\text { ranged between (526) to (688). } \\
\text { The mean amounted (599) } \\
\text { degrees with a standard } \\
\text { deviation of (33.18). } \\
\text { To explain the } \\
\text { summative standard score for } \\
\text { the level of skills in boxing } \\
\text { researcher used the normal } \\
\text { distribution curve for (Carl } \\
\text { Friedrich Gauss) (Allawi and } \\
\text { Radwan, 2000), which is most } \\
\text { commonly used in the field of } \\
\text { physical education, because } \\
\text { many of the Phenomena that } \\
\text { are measured in this field } \\
\text { approaching of the normal } \\
\text { distribution. The normal } \\
\text { distribution curve consists of } \\
\text { (6) standard levels that extend }\end{array}$} & \multicolumn{5}{|c|}{$\begin{array}{l}\text { in the right of the Mean and } \\
\text { three other in the left. } \\
\text { One level = One Z-Score = } 10 \\
\text { T-Score } \\
\text { The standard levels are } \\
\text { benchmarks represents a goal } \\
\text { to be achieved, because they } \\
\text { include scores show the } \\
\text { necessary levels. So, this is } \\
\text { levels set up by individuals } \\
\text { with a high level of } \\
\text { performance. In addition, the } \\
\text { standard level is an internal } \\
\text { basis for evaluating the } \\
\text { phenomenon. And Figure } 1 \text { shows the } \\
\text { standard levels of the } \\
\text { summative standard scores for } \\
\text { students at at Faculty of } \\
\text { Physical Education in Port } \\
\text { Said. }\end{array}$} \\
\hline
\end{tabular}

to (6) deviations three of them 


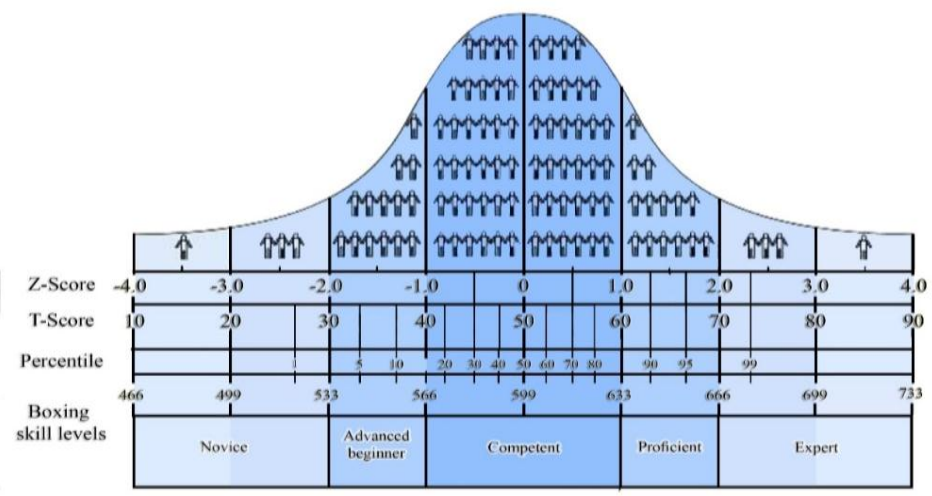

Figure (3). Standard levels of boxing skills battery for students in faculty of physical education Port-Said. (Casella \& Berger,2001).

By using the mean of the summative standard scores for the level of skills, which reached (599 degrees) with a standard deviation was (33.18) and using the distribution of the normal curve of Gaussian. (Casella \& Berger,2001) the researcher reach to Figure (3) which illustrates the five standard levels of skill in boxing for the students of the Faculty of Physical Education in Port Said as follows:

i- $\quad$ Novice (From 466 even less than 533)

If the summative standard score for students at this level, they indicate that this student, novice and had no

previous learning experience in boxing, and he needs to start an educational program.

ii- Advanced beginner (From 533 even less than 566) If the summative standard score for students at this level, they indicate that this student, arrived first compatibility phase, accommodate the basic skills in virtual form and the performance contains many mistakes and shortcomings. In addition, he needs to further learning, teaching, practice, repetition, correction of errors and provide feedback processes.

iii- Competent (From 566 even less than 633)

If the summative standard score for students at this level, they indicate that this student, qualified, can perform basic skills accurate consensus, leads 
skill smoothly and disappear excess movements. But he needs more learning processes and evaluate the performance even up to the mechanism and Proficiency phase.

iv- Proficient (From 633 even less than 666)

If the summative standard score for students at this level, they indicate that this student is competitive and able to perform the skills in difficult conditions did not get used to it previously performed in Super automatic. The goal in this level is to get high through training and focus on the development aspects of physical, physiological and psychological achievement athlete.

v- Expert (From 666 even less than 733)

If the summative standard score for students at this level, they indicate that this student has a great experience in basic skills performance in boxing and could be used as a model for an educational. As well as correcting the mistakes of his colleagues and guide the novice and the transfer of educational experience for them. And often he is a player and an outstanding fought many competitions and recipient of numerous achievements Sports in boxing.

\section{Conclusions}

1. Prepared the Z-scores and $\mathrm{T}$-scores tables for each test Skill in the battery for the students of the Faculty of Physical Education in Port Said as shown in the table (6) to the table (17).

2. Identified standard levels to explain the summative standard score obtained by the student through implementing the battery, as follows:

- $\quad$ Novice (From 466 even less than 533)

- Advanced beginner (From 533 even less than 566)

- Competent (From 566 even less than 633)

- Proficient (From 633

even less than 666)

- $\quad$ Expert (From 666 even less than 733)

\section{Recommendations}

1. Applying the testing battery with their standard score to measure the performance of basic skills in boxing and determine skill level of student in boxing.

2. Build and develop many of the skills test batteries that use modern technologies in the field of boxing, which measure 
different skills so that help specialists in necessary evaluation processes.

3. The construction and development of many of the batteries skills and physical tests in various sports activities because of its great importance in the development and evaluation processes.

\section{References}

1- Allawi, Mohammed Hassan., \& Radwan, Mohammed Nasr al-Din. (2000). The measurement of physical education and sports psychology, 2nd Edition, Cairo: Dar El-Feker El-Araby Press.

2- Al-Zubaidi, Ashraf.(2008). Establishing the evaluation level and giving marks to some of the capabilities and offensive skills for the basketball wheel chair players. Foundation of technical education. Vol 21. Issue 5 .P: 86-99.

3- Anzi,A., Al-saqqi, Ahmed.,\& Dabbagh, Alaab.(2008). Setting standard scores and levels of some basic skills in basketball for the students at Physical Education Department College of Basic Education. Journal of contemporary sport. Vol 7 . Issue 8.

4- Casella, George; Berger, Roger L. (2001). Statistical Inference (2nd ed.). Duxbury. Pacific Grove. USA. P.102

5- Gabbett ,Tim J., \& Georgieff , Boris. (2006). The Development of a Standardized Skill Assessment for Junior Volleyball Players. International Journal of Sports Physiology and Performance, 2006;1:95-107 Human Kinetics, Inc.

6- Hassanein, Mohamed Sobhi (1987). Methods of construction and legalization of tests and standards in physical education. The second edition. Cairo: Dar El-Feker El-Araby Press.

7- Hassanein, Mohamed Sobhi (2003). Measurement and evaluation in physical education and sports. The second part. Fifth edition. Cairo: Dar El-Feker El-Araby Press.

8- $\quad$ Khairy, El-Sayed. Mohamed. (ND), a test of higher intelligence, Arab Renaissance Publishing House, Cairo.

9- Neukrug, Edward \& Fawcett, Charles (2014). Essentials of Testing 
and Assessment: A Practical Guide for Counselors, Social Workers, and Psychologists. Cengage Learning. pp. 133

10- Rakha, Ahmed. (2013). Biomechanical calibration of Mega-strike device to measure the punching force of amateur boxers. The 11th International scientific conference for physical education and movement science - Sport in theory and practice, October 23-25. Faculty of Physical Education. Alexandria University.

11- Rakha, Ahmed. (2016). Design a testing battery to measure the performance of some basic skills in boxing for students at the faculty of physical education. Journal of Applies sports science, Vol 6, No 3, Faculty of Physical Education, Abo Qir, Alexandria University, Egypt.
12- Salum, Ali., Jassim, Mazen., \& Amin, Walid. (2012). Determining standard levels of some basic skills in basketball for the students at first phase in the faculties of Physical Education. Qadisiyah journal Science Physical Education Vol. 12 Issue. 1.

13- Salvia, John; Ysseldyke, James \& Witmer , Sara (2009). Assessment: In Special and Inclusive Education. Cengage Learning. pp. 43.

14- Shehab, Bashar.(2014). Determining grades and standardized levels of my skills progress and retrogression normal young players in the sport of fencing. Journal of Physical Education sciences, Vol. 7. No.

15- Siegfried \& Ellwanger, Ulf. (2008). Boxen Basics, Traning - Technik - Taktik, Pietsch Verlag, Stuttgart, Germany. 